\title{
A cosmogenic nuclide chronology of Cordilleran Ice Sheet configuration during the Last Glacial Maximum in the northern Alexander Archipelago, Alaska
}

5 Caleb K. Walcott ${ }^{1}$, Jason P. Briner ${ }^{1}$, James F. Baichtal ${ }^{2}$, Alia J. Lesnek ${ }^{3}$, Joseph M. Licciardi ${ }^{4}$

${ }^{1}$ Department of Geology, University at Buffalo, Buffalo, NY 14260, USA

${ }^{2}$ Tongass National Forest, Thorne Bay, AK 99919, USA

${ }^{3}$ School of Earth and Environmental Sciences, CUNY Queens College, Flushing, NY 11367, USA

$10{ }^{4}$ Department of Earth Sciences, University of New Hampshire, Durham, NH 03824, USA

Correspondence to: Caleb K. Walcott (ckwalcot@buffalo.edu)

\section{Abstract}

The late-Pleistocene history of the coastal Cordilleran Ice Sheet (CIS) remains relatively

unstudied compared to chronologies of the Laurentide Ice Sheet. Yet accurate reconstructions of

CIS extent and timing of ice retreat along the Pacific Coast are essential for a variety of reasons including paleoclimate modeling, assessing meltwater contribution to the North Pacific, and determining the availability of ice-free land along the coastal CIS margin for human migration from Beringia into the Americas. To improve the chronology of CIS history in the Alexander Archipelago, Alaska, we applied ${ }^{10} \mathrm{Be}$ and ${ }^{36} \mathrm{Cl}$ dating to boulders and glacially sculpted bedrock outcrops in areas previously hypothesized to have remained ice-free throughout the local Last Glacial Maximum (ILGM; 20-17 ka). Results indicate that these sites, and more generally the coastal northern Alexander Archipelago, became ice-free by $15.1 \pm 0.9 \mathrm{ka}(\mathrm{n}=12$ boulders; 1 $\mathrm{SD})$. We also provide further age constraints on deglaciation along the southern Alexander

25 Archipelago and combine our new ages with data from two previous studies. We determine that ice retreated from the outer coast of the southern Alexander Archipelago at $16.3 \pm 0.8 \mathrm{ka}(\mathrm{n}=14$ 
boulders; $1 \mathrm{SD}$ ). These results collectively indicate that areas above modern sea level that were previously mapped as glacial refugia were covered by ice during the 1 LGM until between $\sim 16.3$ and $15.1 \mathrm{ka}$. As no evidence was found for ice-free land during the ILGM, our results suggest that previous ice-sheet reconstructions underestimate the regional maximum CIS extent, and that all ice likely terminated on the continental shelf. Future work should investigate whether presently submerged areas of the continental shelf were ice-free.

\section{Introduction}

The late-Pleistocene history of the coastal Cordilleran Ice Sheet (CIS) remains relatively unstudied compared to chronologies of the Laurentide Ice Sheet (LIS; Dalton et al., 2020). CIS margin reconstructions from the Pacific Coast are based largely on qualitative field observations with little chronologic control (Dyke, 2004; Carrara et al., 2007; Dalton et al., 2020). While a few studies have recently generated local ice sheet retreat chronologies from terrestrial locations along the Pacific Coast (Darvill et al., 2018; Lesnek et al., 2018; Lesnek et al., 2020), there remain vast stretches of the Pacific coastline that lack direct age constraints on deglaciation (Fig. 1). Accurate reconstructions of CIS extent and the timing of ice retreat along the Pacific Coast are essential for paleoclimate modeling, assessing glacial meltwater contributions to the North Pacific and subsequent Northern Hemisphere climate impacts, predicting future mass loss from other marine-terminating ice sheets, and determining whether a coastal route from Beringia into the Americas was viable for humans during southward migration.

Much of the Northern Hemisphere was covered by continental ice sheets during the global Last Glacial Maximum (gLGM; 26 - $19 \mathrm{ka}$ ). While the LIS and many alpine glaciers worldwide were at their greatest extents during this time, the coastal CIS and the Puget Lobe 
reached maximum size $\sim 20$ - 17 ka (local Last Glacial Maximum; hereafter ILGM; Porter and Swanson, 1998; Booth et al., 2003; Praetorius and Mix, 2014; Lesnek et al., 2018).

Accurate constraints of CIS deglaciation are necessary to investigate research topics across numerous disciplines. Recent studies have explored the CIS contributions to meltwater pulse 1A ( 14.6 ka) following the saddle collapse between the LIS and CIS (Gregoire et al., 2016; Ivanovic et al., 2017). Improved constraints on CIS history around meltwater pulse 1A are necessary to elucidate any influences coastal CIS configuration and retreat had on saddle collapse. Additionally, numerical modeling studies show differing responses of the CIS to last deglacial climate oscillations, thus highlighting the need for an improved CIS chronology to bolster model improvement and validation (Tarasov et al., 2012; Seguinot et al., 2014; Gregoire et al., 2016; Seguinot et al., 2016; Ivanovic et al., 2017). Finally, a temporally accurate paleogeographic reconstruction of the coastal CIS margin is required to assess whether a viable coastal route existed for early Americans migrating from Beringia into the Americas. This route hinges on the presence of ice-free land (refugia) suitable for human habitation throughout the ILGM. Earlier mapping efforts and other supporting information indicate areas of potential refugia along the former coastal CIS margin (Demboski et al., 1999; Cook et al., 2001; Carrara et al., 2003; Carrara et al., 2007; Shafer et al., 2010; Shafer et al., 2011).

This study has two goals: 1) to improve the spatio-temporal patterns of coastal CIS deglaciation in southeastern Alaska (SE AK), and 2) to assess whether areas of the northern Alexander Archipelago mapped as refugia were ice-free throughout the ILGM and thus available for human habitation (Fig. 2). We report 25 new cosmogenic ${ }^{10} \mathrm{Be}$ exposure ages from boulders and bedrock from the northern Alexander Archipelago - the first exposure ages documenting CIS retreat from the coastal northern Alexander Archipelago. We also report four ${ }^{10} \mathrm{Be}$ and four 
cosmogenic ${ }^{36} \mathrm{Cl}$ ages from Suemez Island in the southern Alexander Archipelago. Our data constrain the deglaciation of the marine-terminating CIS margin while expanding the overall

North Pacific coastal glacial chronology. Our results suggest deglaciation of coastal regions $\sim 15.4-14.8 \mathrm{ka}$ in the northern Alexander Archipelago and do not support previous mapping that shows refugia in areas that are presently above sea level.

\section{Setting}

80

The Alexander Archipelago, SE AK, stretches $\sim 480 \mathrm{~km}$ (Fig. 2) along the western coast of British Columbia. The southern part of the archipelago is dominated by Prince of Wales Island and surrounding islands, whereas the northern part encompasses Baranof and Chichagof Islands and a collection of smaller islands. The Alexander Archipelago consists of accreted terranes

85 (Cretaceous to Triassic in age) with quartz-bearing diorite and granodiorite units and notable Eocene-Miocene granitic intrusive complexes (Wilson et al., 2015). Late-Pleistocene volcanic activity on southern Kruzof Island formed the Mt. Edgecumbe volcanic field (Riehle, 1996). Post-lLGM (late-Pleistocene and Holocene) eruptions formed extensive andesite flows on the island and blanketed much of the surrounding area with tephra (Riehle et al., 1984; Riehle et al.,

90 1992; Riehle, 1996). Modern climate of the Alexander Archipelago is dominated by cool, wet summers and mild winters, with perennial heavy rainfall (Ager, 2019). Snowfall is minimal at lower elevations, but more substantial in higher elevation areas (https://wrcc.dri.edu/summary/ Climsmak.html). Glaciers occupy alpine cirques in the Alexander Archipelago (totaling $<150$ $\mathrm{km}^{2}$ ), primarily on Baranof and Chichagof islands (Molnia, 2008). Presently, low-elevation (< 
$95700 \mathrm{~m}$ asl) areas of the archipelago are dominated by coniferous rain forests, while alpine tundra exists above the tree line (> $700 \mathrm{~m}$ asl; Ager, 2019).

Previous mapping shows much, if not all, of SE AK covered by the CIS during the ILGM and the last deglaciation, with a maximum position likely terminating several kilometers out on the continental shelf of the Gulf of Alaska (Carrara et al., 2007). Ice caps formed atop the Coast

100 Mountains and high massifs of the Alexander Archipelago, coalesced, and flowed westward to the continental shelf and the Pacific Ocean (Capps, 1932; Mann, 1986; Mann and Hamilton, 1995). Outlet glaciers occupied the present fjord and strait landscape (Carrara et al., 2007). Today, the landscape is strewn with clear indicators of widespread glaciation (deep fjords, glacially sculpted bedrock draped with boulders, and a variety of other glacial landforms), but it

105 remains unclear whether all of SE AK was covered by the CIS during the ILGM. Some areas of the Alexander Archipelago, presently above sea level, were mapped as ice-free throughout the ILGM (Carrara et al., 2007). Recent studies using ${ }^{10} \mathrm{Be}$ surface exposure dating of glacial landforms, however, indicate that some of these areas of hypothesized ice-age refugia in the southern Alexander Archipelago were covered by the CIS during its ILGM advance (Lesnek et al., 2018). Other areas previously interpreted as ice age refugia in the northern Alexander Archipelago are investigated in this study.

Knowledge of the late-Pleistocene glacial history of the southern Alexander Archipelago and areas of coastal British Columbia has recently improved. Radiocarbon-dated marine sediments indicate that the CIS reached its maximum extent sometime between $\sim 25$ and $\sim 18 \mathrm{ka}$ in SE AK (Mann and Hamilton, 1995; Barrie and Conway, 1999; Praetorius and Mix, 2014). Later work, combining ${ }^{14} \mathrm{C}$ dating of terrestrial macrofossils from Shuká Káa and ${ }^{10} \mathrm{Be}$ dating of glacial erratics and sculpted bedrock demonstrated maximum CIS extent in the Prince of Wales 
Island region between $\sim 19.8$ and $\sim 17 \mathrm{ka}$, followed by rapid retreat between $\sim 17$ and $15 \mathrm{ka}$, leading to ice-free inner fjords and sounds by $15 \mathrm{ka}$ and a transition to a primarily landterminating ice sheet thereafter (Lesnek et al., 2018; Lesnek et al., 2020; Baichtal et al., in press). A speleothem from Prince of Wales records a growth hiatus from $41.5 \pm 0.2$ ka to $13.4 \pm 0.2 \mathrm{ka}$, interpreted as the presence of permafrost and/or the CIS over the cave, and thus mean annual air temperatures below $0^{\circ} \mathrm{C}$ during this time (Wilcox et al., 2019). About $400 \mathrm{~km}$ to the south in central coastal British Columbia, CIS deglaciation began $\sim 18.2$ ka on Calvert Island, within maximum $(\sim 27 \mathrm{ka})$ and minimum $(\sim 16 \mathrm{ka})$ terrestrial macrofossil ${ }^{14} \mathrm{C}$ age constraints on nearby Haida Gwaii (Warner et al., 1982; Mathewes and Clague, 2017). Records of alkenone-derived sea surface temperatures (SSTs), ice-rafted debris (IRD), and $\delta^{18} \mathrm{O}$ from marine sediment cores in the Gulf of Alaska show two periods of increased temperatures and concurrent meltwater input at $\sim 17 \mathrm{ka}$ and $\sim 14.7 \mathrm{ka}$ (Kienast and McKay, 2001; Cosma et al., 2008; Davies et al., 2011;

130 Taylor et al., 2014; Maier et al., 2018). The retreat of the CIS in southeastern Alaska and coastal British Columbia is attributed primarily to this ocean warming and eustatic sea level rise at the CIS margins beyond the zero-meter isobase, potentially exacerbated by atmospheric temperature and precipitation changes (Lesnek et al., 2020).

Although recent CIS chronologies from the southern Alexander Archipelago provide new insight into the regional glacial history, few direct ages for CIS deglaciation are available elsewhere along the coastal CIS, including the northern Alexander Archipelago. Basal radiocarbon ages from Hummingbird Lake on southwestern Baranof Island indicate regional CIS deglaciation prior to $15.0 \mathrm{ka}$ (Ager, 2019). Tephra overlying IRD in Sitka Sound and draped across Baranof and several other islands is dated to $14.6 \mathrm{ka}$ and provides a minimum constraint on the retreat of marine-terminating margins onto land (Praetorius et al., 2016). Previous 
mapping (Carrara et al., 2007; Dalton et al., 2020) shows ice-free coastal terrain currently above sea level during the ILGM; if confirmed with numerical dating techniques, this would be a significant confirmation of the existence of coastal refugia.

\section{Methods}

\subsection{Boulder and bedrock sampling}

We collected 29 samples for cosmogenic ${ }^{10} \mathrm{Be}$ surface exposure dating (hereafter ${ }^{10} \mathrm{Be}$ dating) during summer 2018, 2019, and 2020 (Figs. 3 and 4). These included 11 bedrock and 18 boulder samples from Suemez $(n=4)$, Baranof $(n=11)$, Biorka $(n=4)$, Kruzof $(n=4)$ and Chichagof $(\mathrm{n}=6)$ islands. Our samples ranged in elevation from $\sim 50$ to $\sim 930 \mathrm{~m}$ asl; all sites are above the local marine limits of $\sim 10-20 \mathrm{~m}$ asl (Baichtal et al., in press). We preferentially sampled paired sites consisting of stable boulders and neighboring unvegetated bedrock surfaces.

This allows us to assess whether bedrock surfaces contain isotopic inheritance, which helps interpret our suite of ${ }^{10} \mathrm{Be}$ ages and provides insights into ice-sheet erosion history. In the absence of suitable boulders at a few locations, we sampled bedrock with clear evidence of glacial erosion to mitigate the possibility of ${ }^{10} \mathrm{Be}$ inheritance.

We also collected samples from four glacially-transported boulders on the southwestern portion of Suemez Island for ${ }^{36} \mathrm{Cl}$ surface exposure dating during the summer 2019 field season (Figs. 5; 6; Table 2). The boulders consist of non-vesicular olivine basalt of a similar composition to a Pleistocene-aged basalt flow mapped on southwestern Suemez Island by Eberlein et al. (1983). 
Surface samples were collected from the upper few centimeters of the boulders and bedrock using a handheld angle grinder, hammer, and chisel. We avoided sampling areas of the boulder tops and bedrock surfaces with visible signs of surface erosion (e.g., fractures, weathering pits). However, we did observe these features elsewhere on the boulders sampled for ${ }^{36} \mathrm{Cl}$ dating. We recorded sample locations with a handheld GPS unit or GAIA GPS (both with a vertical uncertainty of $\pm 5 \mathrm{~m}$ ) and measured topographic shielding in the field with a clinometer and compass.

\section{2 ${ }^{10}$ Be dating}

We processed samples at the University at Buffalo Cosmogenic Isotope Laboratory following established quartz purification and beryllium extraction procedures (e.g., Corbett et al., 2016). After quartz purification, we dissolved samples in hydrofluoric acid with precisely weighed ${ }^{9}$ Be carrier (PRIME Lab 2017.11.17-Be \#3/\#4; ${ }^{9}$ Be concentration of $1074 \pm 8$ ppm). We isolated, oxidized, and packed beryllium into target cathodes in five different batches for accelerator mass spectrometer (AMS) analysis at PRIME lab at Purdue University. The samples were measured with respect to the $07 \mathrm{KNSTD}$ standard $\left({ }^{10} \mathrm{Be} /{ }^{9} \mathrm{Be}\right.$ ratio of $2.85 \times 10^{-12}$; Nishiizumi et al., 2007). We corrected sample ratios using batch-specific blank values between $7.50 \times 10^{-16}$ and $3.14 \times 10^{-15}$. AMS analytical uncertainty ranged from 3.2 to $7.3 \%$ with an average value of $4.7 \%$.

We calculated all ${ }^{10} \mathrm{Be}$ ages using version 3 of the CRONUS-Earth exposure age calculator (hess.ess.washington.edu; Balco et al., 2008; Balco, 2017), using the Arctic production rate (Young et al., 2013) and a time-dependent (Lm) scaling scheme (Lal, 1991). 


\section{$3 .{ }^{36} \mathrm{Cl}$ dating}

All whole rock samples were prepared at the University of New Hampshire Cosmogenic Isotope Laboratory using a modified version of the protocols in Stone et al. (2000) and Licciardi et al. (2008). Samples were crushed to a $125-250 \mu \mathrm{m}$ grain size, then rinsed in deionized water and leached in a weak $\mathrm{HNO}_{3}$ solution to remove organic material. Each leached sample was homogenized using a riffle splitter and a $\sim 1.2 \mathrm{~g}$ aliquot was removed to determine total sample chloride. The aliquots were spiked with a small amount of ${ }^{37} \mathrm{Cl}$-enriched solution (LLNL Spike $\mathrm{A} ;{ }^{35} \mathrm{Cl} /{ }^{137} \mathrm{Cl}=0.93 ; 1285 \pm 3 \mathrm{ppm} \mathrm{Cl}$ ). Aliquots also received $\sim 4000 \mu \mathrm{g}$ of $\mathrm{Br}$ (in the form of $\mathrm{NH}_{4} \mathrm{Br}$ ), which served to increase the size of the final precipitate. The aliquots were then dissolved in a solution of $\mathrm{HF}$ and $\mathrm{HNO}_{3}$. After dissolution, fluoride compounds were removed by centrifuging. $\mathrm{Ag}(\mathrm{Cl}+\mathrm{Br})$ was precipitated through the addition of $\mathrm{AgNO}_{3}$. The $\mathrm{Ag}(\mathrm{Cl}+\mathrm{Br})$ precipitates were recovered, rinsed, and packed into stainless steel cathodes for measurement of ${ }^{35} \mathrm{Cl} /{ }^{37} \mathrm{Cl}$ ratios, which were used to calculate total sample chloride by isotope dilution methods (Faure, 1986). For the ${ }^{36} \mathrm{Cl}$ extraction, samples received a small amount of natural-ratio $\mathrm{Cl}$ carrier $\left({ }^{35} \mathrm{Cl} /{ }^{37} \mathrm{Cl}=3.127 ; 1436 \pm 9 \mathrm{ppm} \mathrm{Cl}\right)$ to ensure consistent $\mathrm{Cl}$ loads within the analytical batch. All samples received $\sim 4800 \mu \mathrm{g}$ of $\mathrm{Br}$. The samples were dissolved in an $\mathrm{HF}-\mathrm{HNO}_{3}$ solution and insoluble fluorides were removed through centrifuging. $\mathrm{Ag}(\mathrm{Cl}+\mathrm{Br})$ was precipitated by adding $\mathrm{AgNO}_{3}$. The $\mathrm{Ag}(\mathrm{Cl}+\mathrm{Br})$ precipitates were recovered and dissolved in a solution of $\mathrm{NH}_{4} \mathrm{OH}$. To remove ${ }^{36} \mathrm{~S}$, an isobar of ${ }^{36} \mathrm{Cl}, \mathrm{BaNO}_{3}$ was added to the solutions to precipitate $\mathrm{BaSO}_{4}$. The purified $\mathrm{Ag}(\mathrm{Cl}+\mathrm{Br})$ was precipitated by acidifying the solutions with $\mathrm{HNO}_{3}$ and adding $\mathrm{AgNO}_{3}$.

The $\mathrm{Ag}(\mathrm{Cl}+\mathrm{Br})$ precipitates were then recovered, rinsed, and dried. 
measurements ranged from $0.04 \%$ to $0.43 \%$; analytical uncertainty on ${ }^{36} \mathrm{Cl} / \mathrm{Cl}$ measurements ranged from $2.12 \%$ to $2.87 \%$. Major and trace element analyses were conducted by SGS Minerals Services in Burnaby, British Columbia, Canada. Reported total $\mathrm{Cl}$ and ${ }^{36} \mathrm{Cl}$ concentrations are corrected for process blanks (Table 2). Analytical data used to determine surface exposure ages are provided in supplementary tables $\mathrm{S} 1$ and $\mathrm{S} 2 .{ }^{36} \mathrm{Cl}$ exposure ages were calculated using an in-development version of the CRONUS-Earth ${ }^{36} \mathrm{Cl}$ calculator (http://stoneage.ice-d.org/math/Cl36/v3/v3_Cl36_age_in.html) and Lm scaling (Lal, 1991). For comparison, ${ }^{36} \mathrm{Cl}$ ages calculated using version 2.1 of CRONUScalc (Marrero et al., 2016a) are included in supplementary table S3.

\subsection{Exposure age calculation considerations}

We made no corrections for post-glacial elevation changes, post-depositional erosion, or snow cover when calculating our ${ }^{10} \mathrm{Be}$ and ${ }^{36} \mathrm{Cl}$ ages. Post-glacial isostatic adjustment results in a time-varying rate of cosmogenic nuclide production (Jones et al., 2019). This can be corrected for using comprehensive records of regional emergence constrained by glacier isostatic adjustment models or relative sea level histories. Hundreds of radiocarbon ages constrain the relative sea level chronology in the Alexander Archipelago; the sites in our study experienced $\sim 50 \mathrm{~m}$ of relative sea level lowering due to forebulge collapse between $\sim 15$ and $10 \mathrm{ka}$ (Baichtal et al., in press). Corrections for this, albeit slightly uncertain given site-to-site differences in elevation history, result in small changes ( $\sim 1 \%$ age decrease), and thus we report our ages without any correction for isostatic adjustment (Tables 1 and 2). Furthermore, changes in air pressure near a retreating ice margin and shifts in air compression above a sample site that experienced elevation change may mitigate any effects of isostatic adjustment on cosmogenic 
nuclide production, potentially rendering any elevation correction unnecessary (Staiger et al., 2007).

Post-depositional weathering and erosion can also affect exposure ages. We observed fresh, unweathered glacially scoured bedrock across all our field sites, indicating minimal postglacial erosion. Therefore, we made no corrections for erosion in our age calculations.

Extended periods of thick and dense snow cover can also inhibit ${ }^{10} \mathrm{Be}$ and ${ }^{36} \mathrm{Cl}$ production in a rock surface and lead to erroneously young apparent exposure ages. While modern snowfall reports for lower-elevation areas of the Alexander Archipelago indicate minimal average wintertime snow cover $(10-20 \mathrm{~cm}$; https://wrcc.dri.edu/summary/ Climsmak.html), there are no data for higher-elevation areas. Consequently, we cannot report our ages with reliable snow shielding corrections and these exposure dates should be considered minimum ages. However, most of our sites are from low to moderate elevations ( $<500 \mathrm{~m}$ asl; Table 1$)$.

\section{Results}

250

We sampled from the summit of a massif at $\sim 410 \mathrm{~m}$ asl on south-central Suemez Island (southern Alexander Archipelago) and from a flat bench scattered with boulders on the summit's flank for ${ }^{10} \mathrm{Be}$ dating (Fig. 6). The two boulders sampled on the bench date to $15.6 \pm 0.7$ (19SEAK-07; Fig. 3) and 15.0 \pm 1.1 ka (19SEAK-08; we report all surface exposure ages with 1 $\sigma$ internal uncertainty; Table 1.). The summit site featured fresh glacially sculpted bedrock surfaces with a couple boulders resting on the bedrock. A boulder and its adjacent bedrock surface, as a pair, date to $17.4 \pm 1.2$ (19SEAK-09) and 19.7 $\pm 1.2 \mathrm{ka}$ (19SEAK-10), respectively (Fig. 3). The three boulders yield a mean age of $16.0 \pm 1.2 \mathrm{ka}(\mathrm{n}=3 ; 1 \mathrm{SD})$. 
On southwestern Suemez Island, we sampled four large boulders for ${ }^{36} \mathrm{Cl}$ dating. The boulders were distributed across a terrain of patchy muskeg with locally outcropping bedrock. Based on reconstructed CIS flow directions (Lesnek et al., 2020) and boulder composition (supplementary table S2; Eberlein et al., 1983), the boulders were likely plucked from basalt flows present on the southwestern portion of Suemez Island (Brew, 1996). The four basalt boulders from southwestern Suemez Island have ${ }^{36} \mathrm{Cl}$ exposure ages ranging from $12.5 \pm 1.1$ to $16.6 \pm 1.6 \mathrm{ka}$ (ages are reported at $1 \sigma$ internal uncertainty; Fig. 5; Table 2).

We collected samples from four sites (Baranof Sites A - D; Fig. 7) on the ocean-facing side of Baranof Island, northern Alexander Archipelago. Here, we chose our helicopter ground stops in an area previously mapped as ice-free throughout the ILGM (Carrara et al., 2007; Fig. 7). Evidence for glacial sculpting of bedrock surfaces is clear; glacial grooves, striations and chatter marks are present at all sites, and the bedrock surfaces, in places, are topped by perched boulders (Fig. 3). Field evidence of recent glaciation, including relatively unweathered chatter marks, grooves, and striations, contradicts prior mapping of these areas being ice-free during the ILGM.

Baranof Site A is a large, unforested area of bedrock outcrops composed of several smaller ridges. Here, we sampled two bedrock surfaces - one from the stoss side of a bedrock outcrop (19SEAK-18; Fig. 3) and one from the top surface of a nearby bedrock patch (19SEAK19) - which date to $21.7 \pm 0.9$ and $28.0 \pm 1.1 \mathrm{ka}$, respectively. A boulder sampled adjacent to bedrock (sample 19SEAK-18) yielded an exposure age of $16.9 \pm 0.8 \mathrm{ka}$ (19SEAK-17). A second boulder sample from this stop dates to $14.4 \pm 0.7 \mathrm{ka}$ (19SEAK-20; Fig. 3). At Baranof Site B - a raised bedrock knob - we sampled two boulders and one bedrock surface. The two boulders have

${ }^{10} \mathrm{Be}$ ages of $15.1 \pm 0.6 \mathrm{ka}$ (19SEAK-23; Fig. 3), $14.4 \pm 0.7 \mathrm{ka}$ (19SEAK-21); the bedrock 
samples has a ${ }^{10} \mathrm{Be}$ age of $14.4 \pm 0.6 \mathrm{ka}(19 \mathrm{SEAK}-22)$. Baranof Site $\mathrm{C}$ is a high ridge between the ocean and a U-shaped valley with abundant bedrock outcrops and few boulders. Here, a boulder yielded an exposure age of $16.3 \pm 0.6 \mathrm{ka}$ (19SEAK-24; Fig. 3) whereas a bedrock surface dates to $15.7 \pm 0.6 \mathrm{ka}(19 \mathrm{SEAK}-25)$. Finally, Baranof Site D is a small bedrock ridge between two peaks with massive stoss and lee features. At this site, we collected samples from two quartz veins in the bedrock, which have exposure ages of $18.2 \pm 0.7$ (19SEAK-26; Fig. 3) and $20.2 \pm 0.8 \mathrm{ka}$ (19SEAK-27). Because the sites are all in relatively close proximity and from similar elevations $(50-160 \mathrm{~m}$ asl), we treat the samples as having experienced the same glacial history, and thus should belong to a single age population. Collectively, boulder samples yield a mean age of 15.4 $\pm 1.1 \mathrm{ka}(\mathrm{n}=5 ; 1 \mathrm{SD})$ with no obvious outliers, whereas the bedrock samples exhibit more scatter and are mostly older than the mean boulder age (Fig. 9).

Biorka Island, a small island off the western coast of central Baranof Island, was initially mapped as ice-covered throughout the ILGM (Dyke, 2004). Here, there are numerous $\sim 1 \mathrm{~m}$ tall boulders that rise above the surrounding vegetation and rest on ice-sculpted bedrock. Vegetation and sediments mostly obscure underlying bedrock surfaces, and thus we only collected samples from boulders at this sampling site. Our four boulder samples yielded exposure ages of $15.3 \pm$ 0.5 (18JB005; Fig. 4), $14.9 \pm 0.6$ (18JB006), $15.4 \pm 0.5$ (18JB007; Fig. 4), and $13.7 \pm 0.5 \mathrm{ka}$ 18JB008), with a mean of $14.8 \pm 0.8 \mathrm{ka}(\mathrm{n}=4 ; 1 \mathrm{SD}$; Fig. 8). northwestern Kruzof Island, previously mapped as ice-free throughout the LGM (Dalton et al., 2020). There, we found many large stable boulders and exposed patches of glacially sculpted bedrock between vegetation exhibiting glacial grooves and chatter marks. Here, we sampled three large boulders ( $>2 \times 2 \times 1 \mathrm{~m})$, which date to $14.9 \pm 0.8$ (20SEAK-07; Fig. 4), $14.9 \pm 0.9$ 
(20SEAK-12) and $14.6 \pm 0.8 \mathrm{ka}$ (20SEAK-13; Fig. 4), yielding a mean age of $14.8 \pm 0.2 \mathrm{ka}(\mathrm{n}=$ 3; 1 SD; Fig. 8). A bedrock surface at this site dates to $13.4 \pm 1.0 \mathrm{ka}$ (20SEAK-10; Fig. 4) and sits $\sim 10 \mathrm{~m}$ below and $\sim 10 \mathrm{~m}$ away from the boulder that dated to $14.6 \pm 0.8 \mathrm{ka}$ (20SEAK-13).

We collected samples from three sites on Chichagof Island (Chichagof Sites A - C; Fig. 8). Unlike our other sampling locations which are on the ocean-facing, western sides of the archipelago, the Chichagof Island sites are all located inland. We visited these sites to determine the timing of ice retreat inland and to complement the findings of a previous study that documented ice withdrawal in the central and eastern Alexander Archipelago (Lesnek et al., 2020). Chichagof Island is notable for its relative lack of boulders - consequently, the boulders sampled here are smaller than those at other sites. While many bedrock outcrops featured smooth

315 surfaces indicative of glacial erosion, we did not observe clear striations or chatter marks. At site A, a bedrock bench, ${ }^{10} \mathrm{Be}$ ages from two small, perched boulders are $12.7 \pm 0.7$ (20SEAK-15; 0.5 x $0.3 \times 0.3 \mathrm{~m} ; 476 \mathrm{~m}$ asl; Fig. 4) and $9.0 \pm 0.6 \mathrm{ka}(20$ SEAK-16; $0.5 \times 0.4$ x $0.3 \mathrm{~m} ; 473 \mathrm{~m}$ asl). A quartz vein sampled from bedrock outcrop at this site has an exposure age of $15.3 \pm 0.7 \mathrm{ka}$ (20SEAK-14). Site B is a series of bedrock ridges, and a single boulder yields an exposure age of $12.4 \pm 0.9 \mathrm{ka}$ (20SEAK-18; $817 \mathrm{~m}$ asl; Fig. 4), while an adjacent bedrock surface dates to $14.1 \pm$ $0.7 \mathrm{ka}$ (20SEAK-19; $816 \mathrm{~m}$ asl). Finally, site $\mathrm{C}$ is at the summit of a massif and one bedrock knob sampled here has an exposure age of $17.7 \pm 0.8 \mathrm{ka}$ (20SEAK-22; $779 \mathrm{~m}$ asl; Fig. 4).

\section{Discussion}

\subsection{Bedrock ${ }^{10}$ Be ages}

We sampled large and stable boulders in addition to bedrock surfaces with clear evidence of glacial erosion (e.g., striations, chatter marks) with the goal of providing optimal constraints on 
deglaciation. Sampling bedrock surfaces also allows us to better understand the subglacial erosion regime across the Alexander Archipelago, potentially yielding information about the duration of ice cover, the amount of subglacial erosion, and the likelihood of boulders containing inheritance.

Bedrock exposure ages are older than the mean boulder exposure ages by two SD or greater on Suemez Island (19SEAK-10) and Baranof sites A (19SEAK-18, 19SEAK-19) and D (19SEAK26, 19SEAK-27). At Chichagof site A the bedrock exposure age (20SEAK-14) is 4.5 kyr older than the mean boulder age, but still within two standard deviations, perhaps due to the large spread in boulder ages resulting in larger standard deviations. At Chichagof site B, the single boulder ${ }^{10} \mathrm{Be}$ age (20SEAK-18) post-dates the single bedrock age by $\sim 1.7 \mathrm{kyr}$. In general,

340 bedrock data reported here are consistent with bedrock ${ }^{10} \mathrm{Be}$ ages from Warren and Baker islands that are older (by more than 2 SD) than mean boulder ages (Lesnek et al., 2018). Bedrock ages may be erroneously older due to ${ }^{10} \mathrm{Be}$ inheritance if ice sheet erosion was insufficient to remove the $\sim 2 \mathrm{~m}$ of rock required to remove most of the previous ${ }^{10} \mathrm{Be}$ inventory. Studies from British Columbia (Darvill et al., 2018) and Washington (Briner and Swanson, 1998) also report cosmogenic nuclide inheritance in bedrock from other areas covered by the CIS. In our field area, the short-lived nature of the overriding event ( $\sim 3 \mathrm{kyr}$; Lesnek et al., 2018) may also contribute to the lack of significant glacial erosion. Finally, traces of inheritance may be present in bedrock, perhaps even boulders, in ice-sheet-distal sites like these that are overrun by ice during extremely brief portions of the Quaternary (Briner et al., 2016).

In some cases, boulder-bedrock pairs have similar exposure ages (on southern Baranof and Suemez islands), suggesting our bedrock ages are unaffected by ${ }^{10} \mathrm{Be}$ inheritance at these sites. On Kruzof Island, a bedrock patch yields an exposure age that is younger (by more than 2 
$\sigma)$ than the mean age of the surrounding boulders. Potential cover by snow, sediment, or vegetation is thought to have caused anomalously young ages elsewhere in the Alexander Archipelago (Lesnek et al., 2020) and may also explain this ${ }^{10} \mathrm{Be}$ age from our bedrock site on Kruzof Island.

Bedrock exposure ages vary greatly (by as much as $\sim 14 \mathrm{kyr}$ ) between the various sampling locations on Baranof Island and up to $6 \mathrm{kyr}$ on Suemez Island (Lesnek et al., 2018). The Alexander Archipelago is characterized by impressive relief (deep fjords, high peaks), and thus, sub-glacial erosion rates clearly varied greatly across Suemez and Baranof islands where sampling locations are $\sim 2-6 \mathrm{~km}$ apart. Differing bedrock ${ }^{10} \mathrm{Be}$ ages from the same sampling locales confirm this, reflecting variable sub-glacial erosion rates even within $\sim 100 \mathrm{~m}$ of each other. Some samples may have been collected in areas dominated by glacial abrasion, whereas other samples might be from surfaces dominated by quarrying, and thus, this variability could reflect varying subglacial processes on a local scale.

Because bedrock exposure ages from the coastal Alexander Archipelago (this study; Lesnek et al., 2018) do not consistently pre-date, match, or post-date exposure ages from adjacent boulders, we refrain from including bedrock-based ${ }^{10} \mathrm{Be}$ ages in our mean age calculations (Figs. 9; 10). This negates biases when choosing which bedrock ages "match" nearby erratic ages and allows us to eliminate any concern over inheritance or post-ice retreat cover of these bedrock surfaces. While bedrock ages, especially when paired with boulder ages, are useful for identifying spatially variable subglacial erosion processes and issues with past cover and inheritance, they do not provide reliable age constraints on the timing of deglaciation. In light of this, we also recalculate relevant mean ages from Lesnek et al. $(2018 ; 2020)$ using solely boulder ${ }^{10} \mathrm{Be}$ ages to update these other regional chronologies. 


\section{$5.2{ }^{10}$ Be chronology incompatible with mapped Cordilleran Ice Sheet extent}

We targeted areas of the northern Alexander Archipelago mapped as ice-free by previous studies to determine whether these areas were ILGM refugia. The most recent coastal CIS reconstructions show significant portions of the northern Alexander Archipelago as remaining ice-free throughout the ILGM (Fig. 2), with ice terminating close to the present shoreline - not on the continental shelf (Dalton et al., 2020; Lesnek et al., 2020). Our data, however, indicate that at least some of these areas that were mapped as refugia (southwestern Baranof and Kruzof islands) were covered by ice, and deglaciated around $15.4-14.8 \mathrm{ka}$. Our new evidence thus suggests that ice extended onto the continental shelf during the ILGM, as in the southern Alexander Archipelago (Lesnek et al., 2018). These discrepancies between previously mapped ice extents and those implied by our new exposure ages highlight the need to develop deglaciation chronologies elsewhere along the CIS coastal margin to provide updated mapping around the north Pacific.

\subsection{Cordilleran Ice Sheet retreat across the Alexander Archipelago}

Mean boulder ${ }^{10} \mathrm{Be}$ exposure ages from Suemez Island in this study and Lesnek et al. (2018), $16.0 \pm 1.2 \mathrm{ka}(\mathrm{n}=3$ boulders; $1 \mathrm{SD})$ and $16.6 \pm 0.8 \mathrm{ka}(\mathrm{n}=3$ boulders; $1 \mathrm{SD})$, overlap within 1 standard deviation (Figs. 6; 9). However, three of the boulder ${ }^{36} \mathrm{Cl}$ ages from southwestern Suemez Island do not overlap with the ${ }^{10} \mathrm{Be}$ ages, at 1 standard deviation (Figs. 6; 9). We attribute this scatter to post-depositional surface erosion of the boulders. Surface erosion of rocks with low concentrations of native $\mathrm{Cl}$ (supplementary table $\mathrm{S} 2$ ), where the primary ${ }^{36} \mathrm{Cl}$ production pathway is Ca-spallation (Marrero et al., 2016b), results in exposure ages that are 
erroneously young. Thus, we interpret the oldest ${ }^{36} \mathrm{Cl}$ exposure age (16.6 $\pm 0.5 \mathrm{ka}$; 19SEAK-02) as the closest constraint on deglaciation at that site. This ${ }^{36} \mathrm{Cl}$ age overlaps with the ${ }^{10} \mathrm{Be}$ ages from elsewhere on Suemez Island; we combine them and calculate a new, boulder-based mean deglaciation age of $16.3 \pm 0.8 \mathrm{ka}(\mathrm{n}=10$ boulders; $1 \mathrm{SD})$ for Suemez Island.

We group together three of our sampling locations in the northern Alexander Archipelago that are ocean-facing: Kruzof, Biorka, and southern Baranof islands. As the CIS retreated from the continental shelf inland, these were the first areas presently above sea level to become icefree. We calculate a mean ${ }^{10} \mathrm{Be}$ boulder age of $15.1 \pm 0.9 \mathrm{ka}(\mathrm{n}=12$ boulders; $1 \mathrm{SD})$ for the coastal northern Alexander Archipelago.

There are limited data from elsewhere in the northern Alexander Archipelago that 410 constrain the timing of deglaciation. A basal pollen concentrate-based radiocarbon age from Hummingbird Lake (Fig. 7), southwestern Baranof Island dates to $15.0 \pm 0.2 \mathrm{ka}$, in agreement with the ${ }^{10} \mathrm{Be}$ ages presented here and that collectively indicate coastal Baranof Island was deglaciated prior to this (Ager, 2019). Additionally, tephra layers from Mt. Edgecumbe on Kruzof Island are dated to 13.1 ka (Riehle et al., 1992; Beget et al., 1998), and blanket many of 415 the surrounding islands, suggesting that these areas were ice-free by then.

All three sample sites on Chichagof Island (Sites A - C) are not ocean-adjacent and characterized by a general lack of boulders. The boulders present were much smaller, and notably, shorter $(<0.5 \mathrm{~m}$ high) than boulders sampled elsewhere across the Alexander Archipelago - we chose to sample these despite their size to provide minimum ages for and $12.7 \pm 0.7 \mathrm{ka}$. Their ages are younger than other age constraints for deglaciation on Chichagof Island; radiocarbon ages on shells from raised marine terraces on Chichagof Island 
date back to $14.2 \pm 0.6$ cal ka suggesting that the island was ice-free by this time (Baichtal et al., in press). Smaller boulders are more susceptible to cover (whether snow, vegetation, or sediment), and may thus yield anomalously young ${ }^{10} \mathrm{Be}$ ages. While a lack of large boulders found on Chichagof Island make it difficult to ascertain the timing of deglaciation, regional glacial and sea level history suggests Chichagof Island was deglaciated between 15.1 (when the coastal area deglaciated) and $14.2 \mathrm{ka}$ (the age of shells in raised marine deposits). Therefore, our boulders likely have anomalously young exposure ages. Archipelago of $15.1 \pm 0.9 \mathrm{ka}$ ( $\mathrm{n}=12$ boulders; $1 \mathrm{SD})$ fits with the few other regional deglaciation constraints (Fig. 2) and overlaps within one standard deviation with the mean boulder exposure age from the southern Alexander Archipelago of $16.3 \pm 0.8 \mathrm{ka}(\mathrm{n}=13$ boulders; $1 \sigma$; this study; Lesnek et al., 2018; Lesnek et al., 2020).

While mean ages from the northern and southern Alexander Archipelago overlap within one standard deviation, it is possible that these areas deglaciated at slightly different times as these various sampling sites happened to become ice-free. Furthermore, local ice caps formed and radiated from massifs on Chichagof, Baranof, and Prince of Wales islands during the 1LGM (Capps, 1932; Mann and Hamilton, 1995; Lesnek et al., 2020). These local ice caps served as a

440 local ice source for the Alexander Archipelago and their locations and flow patterns may have led to some parts of the archipelago becoming ice-free before others. Thus, we present a range of deglaciation across the coastal Alexander Archipelago from between $16.3 \pm 0.8 \mathrm{ka}$ and $15.1 \pm$ $0.9 \mathrm{ka}$

Ice retreat across the Alexander Archipelago is also registered in marine sediments off the former coastal CIS margin. Several marine sedimentary records (cores EW0408-26JC, 
EW0408-66JC, EW0408-85JC) extending back to $\sim 18.5$ cal ka show the presence of IRD beginning $\sim 18.5 \mathrm{ka}$, peaking at $17.5-16.5 \mathrm{ka}$ and ceasing at $14.8 \mathrm{ka}$, reflecting a final retreat of marine-terminating ice (Praetorius and Mix, 2014). Furthermore, these IRD data record fluctuating but relatively elevated calving spanning 18.5 to $14.8 \mathrm{ka}$, perhaps indicating steady retreat punctuated by periods of accelerated melting.

Tephra from Mt. Edgecumbe (Kruzof Island) found in core EW0408-26JC is interpreted as being deposited in a submarine environment, suggesting that this core site was ice-free by 14.6 ka (Praetorius et al., 2016). Records of a subsequent eruption dated to $\sim 13.1 \mathrm{cal}$ ka from marine sediments in Sitka Sound (core EW0408-40JC) indicate that this area (between Baranof and Kruzof islands) must have been ice-free by this time (Addison et al., 2010). Finally, ${ }^{14} \mathrm{C}$ ages from mollusks found in a diamicton layer along the Gastineau Channel date to $\sim 13.8 \mathrm{cal} \mathrm{ka}$, reflecting the beginning of deglaciation near the mainland (Miller, 1973; we calibrate all uncalibrated ${ }^{14} \mathrm{C}$ ages with CALIB 8.2; Stuiver et al., 2021).

\subsection{Chronologies of Cordilleran Ice Sheet deglaciation across the North Pacific}

Radiocarbon ages from the CIS margin reflect ice advance from $20-17 \mathrm{ka}$, near the end of the gLGM at 19 ka. Dates from mammalian fossils in Shuká Káa on Prince of Wales Island indicate CIS advance $\sim 20 \mathrm{ka}$ in the Alexander Archipelago (Lesnek et al., 2018). Directly south of the Alexander Archipelago, on eastern Graham Island (Haida Gwaii) initial ice advance is dated to $24.1-22.5$ cal ka with a ${ }^{14} \mathrm{C}$ date from a twig underlying glacial till (Blaise et al., 1990; Mathewes and Clague, 2017). Along the southwestern CIS margin, ice reached its maximum extent until $\sim 18.3 \mathrm{ka}$ in the Coquitlam Valley and $\sim 17.0 \mathrm{ka}$ in the Puget Sound area (Clague et al., 1980; Porter and Swanson, 1998). 
retreat. On Sanak Island, tephra near the bottom of a lake sediment core dates deglaciation before $\sim 15.9 \mathrm{ka}$, prior to the onset of CIS withdrawal in the Alexander Archipelago (Misarti et al., 2012). On Kodiak Island, final 1 LGM retreat dates to $\sim 15.7 \mathrm{cal} \mathrm{ka}$, as marked by a ${ }^{14} \mathrm{C}$ age above glacio-tectonically altered sediments (Mann and Peteet, 1994). Directly north of the Alexander Archipelago, $\mathrm{a}^{14} \mathrm{C}$ age from a log found within the Finger Glacier lateral moraine provides a minimum constraint on deglaciation at $\sim 14.6 \mathrm{cal} \mathrm{ka}$ (Mann, 1986). Radiocarbon ages from a marine sediment core in Dixon Entrance date maximum CIS extent to before $\sim 16.1 \mathrm{cal}$ ka and retreat beginning before $\sim 15.3 \mathrm{cal} \mathrm{ka}$ (Barrie and Conway, 1999). A marine sediment record from Vancouver Sound similarly dates maximum ice extent to $18.5 \mathrm{ka}$ and retreat of the CIS onto the mainland by $16.4 \mathrm{ka}$ (Blaise et al., 1990). Quaternary sediments on eastern Graham Island indicate the CIS was retreating by $17.8 \mathrm{cal}$ ka (Blaise et al., 1990). Notably, ${ }^{10} \mathrm{Be}$ ages on Calvert Island suggest ice retreated off the continental shelf at $\sim 18 \mathrm{ka}$, pre-dating ice withdrawal onto land in the Alexander Archipelago (Darvill et al., 2018).

Marine sediment cores are interpreted to show ice retreat across the coastal northeastern Pacific. A marine sediment core (SO202-27-6) from the Gulf of Alaska captures a decrease in sea surface salinity $\sim 16 \mathrm{ka}$, interpreted to reflect increased meltwater from the CIS margin (Maier et al., 2018). Another marine sediment core (EW0408-85JC) from off the coast of southern Alaska records a decrease in glacial-margin sediment accumulation at $16.9 \mathrm{ka}$ as ice stagnated or began to retreat. (Davies et al., 2011). Reductions in salinity captured by planktonic $\delta^{18} \mathrm{O}$ in this core at $\sim 16.7 \mathrm{ka}$ are interpreted as an increase in meltwater input from retreating glaciers. A transition from ice-proximal to laminated hemipelagic sediments at $\sim 14.8$ ka marks glacier retreat off the continental shelf and onto land. Additionally, a marine sediment core from 
off Vancouver Island (MD02-2496) captures IRD deposition between $\sim 17.0$ and $\sim 16.2 \mathrm{cal} \mathrm{ka-}$ indicating rapid regional deglaciation - and a minor IRD event at $\sim 14.7$ cal ka (Cosma et al., 2008).

Our new data showing ice retreat at $15.1 \pm 0.9$ ka from the northern Alexander Archipelago, along with ages of deglaciation from the southern Alexander Archipelago (16.3 \pm $0.8 \mathrm{ka}$; this study; Lesnek et al., 2018), are broadly synchronous with previously published ice retreat chronologies for the marine-terminating CIS margin elsewhere along the northeast Pacific Coast. However, while our chronology only documents deglaciation, it provides further evidence of a delayed ILGM across the coastal CIS compared to the gLGM maximum extents of alpine glaciers in mainland Alaska (Briner et al., 2017), parts of southern Alaska (Reger et al., 1996), and the LIS (Dalton et al., 2020).

\subsection{Paleoclimate Records from the North Pacific}

Several paleoclimate records from around the North Pacific span our interval of CIS deglaciation in the Alexander Archipelago. A combined diatom assemblage- and alkenone-derived record of sea surface temperatures (SSTs) from the Bering Sea (Core 51JPC), records perennial sea ice from $\sim 22.5 \mathrm{ka}$ (beginning of record) to $17 \mathrm{ka}$, and increased SSTs beginning $\sim 16.9$ ka before a notable shift back to annual sea ice $\sim 16.7 \mathrm{ka}$ (Caissie et al., 2010). In the northern Gulf of Alaska (Core EW0408-85JC), $\delta^{18} \mathrm{O}$ data document increasing SSTs at $16.7 \mathrm{ka}$ and again at $\sim 14.7 \mathrm{ka}$ (Davies et al., 2011). Alkenone-inferred paleo-SST reconstructions from this same core show the lowest SSTs $\left(\sim 5^{\circ} \mathrm{C}\right)$ circa $17.0 \mathrm{ka}$, with increased SSTs beginning $\sim 16.5 \mathrm{ka}$, and a rapid $\sim 3-4{ }^{\circ} \mathrm{C}$

515 rise in SSTs from 15.2 to $14.7 \mathrm{ka}$ (Praetorius et al., 2015). Alkenone-inferred SST and $\delta^{18} \mathrm{O}$ records from the Gulf of Alaska also record increased SSTs of $\sim 3^{\circ} \mathrm{C}$ at $14.7 \mathrm{ka}$ (cores EW0408- 
26JC, EW0408-66JC; Praetorius et al., 2016). Off Vancouver Island, Mg/Ca temperature reconstructions from subsurface-dwelling $N$. pachyderma indicate two stages of warming of $2^{\circ} \mathrm{C}$ at $17.2-16 \mathrm{ka}$, and $15.5-14.0 \mathrm{ka}$, while surface-dwelling G. bulloides record a $3^{\circ} \mathrm{C}$ SST increase from 15.0 - $14.0 \mathrm{ka}$ (core MD02-2496; Taylor et al., 2014), all within uncertainty of coastal Alexander Archipelago ice retreat. Alkenone SST reconstructions from another nearby core (core JT96-09) also indicates a $4^{\circ} \mathrm{C}$ increase in SST at $\sim 14.7 \mathrm{ka}$ (Kienast and McKay, 2001).

There are few terrestrial paleoclimate data that span the last deglacial period from SE AK and coastal British Columbia. Cordilleran ice cover until $\sim 15$ ka across much of the region impeded the preservation of many terrestrial records - however, there are limited ice core, speleothem, and lake records that date back to early regional deglaciation or prior. Fisher et al. (2008) developed an ice core record from Mt. Logan, British Columbia. However, measurements of $\delta^{18} \mathrm{O}$ likely represent shifting precipitation sources, rather than paleoclimate changes. A growth hiatus in a speleothem from El Capitan Cave (southern Alexander Archipelago) spanning $\sim 41.5$ to $\sim 13.4$ ka suggests the cave was either overridden by the CIS, experienced permafrost conditions and a mean annual air temperature $<0^{\circ} \mathrm{C}$, or lacked drip water (Wilcox et al., 2019). However, El Capitan Cave is $\sim 60 \mathrm{~km}$ inland of the outermost coastal region and therefore may have still experienced these conditions while the outer coast deglaciated. At Hummingbird Lake, southwestern Baranof Island, pollen records indicate Pinus contorta dominated from $\sim 15.2$ ka to $14 \mathrm{ka}$, which is interpreted to represent Pinus contorta response to the beginnings of Gulf of Alaska ocean warming at $\sim 16.5 \mathrm{ka}$ (Praetorius et al., 2015; Ager, 2019). This record suggests increased air temperatures around deglaciation of the Alexander Archipelago between $16.3 \pm 0.8$ ka and $15.1 \pm 0.9 \mathrm{ka}$ 


\subsection{Implications for early human migration}

Several studies have focused on scrutinizing potential areas of ILGM glacial refugia in the Alexander Archipelago through a human migration perspective (Carrara et al., 2007; Lesnek et al., 2018), building off similar approaches from elsewhere in the North Pacific (e.g., Warner et al., 1982; Mann and Peteet, 1994; Misarti et al., 2012). Our study focused on southern Baranof and Kruzof islands because previous mapping suggested that parts of these areas were ice-free throughout the ILGM (Carrara et al., 2003; Carrara et al., 2007). However, our ${ }^{10}$ Be ages from southern Baranof Island indicate these areas were glaciated throughout the ILGM and not available for human habitation between $\sim 20 \mathrm{ka}$ and $\quad \sim 15.4 \mathrm{ka}$. Our exposure ages from Kruzof Island also suggest that this area was not ice free until $\sim 14.8 \mathrm{ka}$.

These results indicate that some of the last major unevaluated areas of possible refugia that are presently above sea-level were covered by ice during the lLGM. At its maximum extent, ice likely extended onto the then-exposed continental shelf. Ice occupation of the continental shelf - or at least parts of the shelf - off the Alexander Archipelago was relatively brief, from $\sim 20.0$ to $\sim 16.0 \mathrm{ka}$ (Lesnek et al., 2018). Lowered global sea levels indicate the shelf would have been above contemporary sea level during this time and until $\sim 11-8 \mathrm{ka}$, when sea level neared modern levels in the Alexander Archipelago (Baichtal et al., in press). At a minimum, ice lobes would have existed within the major shelf troughs (e.g., Chatham Strait), likely crossing the entire shelf at these locations; at a maximum, the whole continental shelf may have been occupied by ice from $\sim 20$ to $\sim 16 \mathrm{ka}$. Whether portions of the shelf remained ice-free during the ILGM is unknown, but it is possible. Based on the immediate colonization of Pinus at $15.2 \mathrm{ka}$ in Hummingbird Lake, and as early as $\sim 15.4$ ka on Pleasant Island, there were likely ice-free areas on the shelf throughout the ILGM (Hansen and Engstrom, 1996; Ager, 2019). 


\section{Conclusions}

565

We conclude that several areas in SE AK previously mapped as ice-free through the ILGM were covered by ice until between $\sim 16.3$ and $\sim 15.1 \mathrm{ka} .{ }^{10} \mathrm{Be}$ ages from boulders suggest that the northern coastal Alexander Archipelago deglaciated at $15.1 \pm 0.9$ ka , while ${ }^{10} \mathrm{Be}$ and ${ }^{36} \mathrm{Cl}$ ages date ice retreat in the southern portion at $16.3 \pm 0.8 \mathrm{ka}$, following a $1 \mathrm{LGM}$ that begin after $\sim 20 \mathrm{ka}$ (Lesnek et al., 2018; Lesnek et al., 2020) The timing of deglaciation in the Alexander Archipelago is similar to some other sites around the CIS coastal margin (e.g., Mann and Peteet, 1994; Misarti et al., 2012), but later than other locations (e.g., Darvill et al., 2018). Notably, the deglaciation in SE AK is later than in mainland Alaska and Kodiak and Sanak Islands, Alaska, where records are more aligned with the gLGM. The timing of deglaciation in the Alexander Archipelago is broadly synchronous with regional records of local ocean and air temperature increases. We also found that anomalously old ${ }^{10} \mathrm{Be}$ ages of bedrock surfaces are due to inheritance caused by insufficient ice sheet erosion, and thus, we caution using ages from bedrock surfaces as direct constraints on ice retreat without additional boulder ages along the coastal margins of the CIS.

Our data indicate that previous mapping of the coastal CIS can be spatially and temporally improved. We suggest that ice likely extended out on the continental shelf along the Alexander Archipelago. We are increasingly confident that areas of the coastal CIS mapped as ice-free throughout the ILGM were in fact covered by ice, and that refugia, if any, would have been located on the exposed continental shelf. Although more logistically challenging, subsequent studies should evaluate the existence of ILGM refugia in the Alexander Archipelago by focusing on the previously exposed continental shelf. Special attention should be given to the northern Alexander Archipelago where ice masses were fed by local ice caps and thus may not 
have been as extensive, as opposed to elsewhere in the northeastern Pacific where ice was sourced from the main body of the CIS.

\section{Acknowledgements}

We acknowledge that these samples were collected on the ancestral lands of the Tlingit and that the University at Buffalo exists on the land of the Seneca. These peoples are the traditional caretakers of these lands and we give thanks for the opportunity to exist and work on lands that are rightfully theirs. We thank the Tongass National Forest for assistance with permitting and logistics. We thank Corey Krabbenhoft, Joseph Tulenko and Karlee Prince for field assistance and Joseph Tulenko and Chris Sbarra for lab assistance. We also thank PRIME Lab for ${ }^{10} \mathrm{Be}$ measurements and Lawrence Livermore National Laboratory for ${ }^{36} \mathrm{Cl}$ measurements. This research was funded by NSF (award \# 1854550), the National Geographic Society (award \# 57989R-19), a Geological Society of America Student Research Grant (grant number 13631) funded by NSF (award \# 1949901), the Alaska Geological Society, and the Mark Diamond Research Fund of the Graduate Student Association at the University at Buffalo, the State University of New York. 


\section{References}

Addison, J. A., Beget, J. E., Ager, T. A., and Finney, B. P.: Marine tephrochronology of the Mt. Edgecumbe volcanic field, southeast Alaska, USA, Quaternary Research, 73, 277-292, 2010.

Ager, T. A.: Late Quaternary vegetation development following deglaciation of northwestern Alexander Archipelago, Alaska, Frontiers in Earth Science, 7, 104, 2019.

Baichtal, J. F., Lesnek, A. J., Carlson, R. J., Schmuck, N., Smith, J. L., Landwehr, D. J., and Briner, J. P.: Late Pleistocene and Early Holocene Sea level History Glacial Retreat Interpreted from Shell-bearing Marine Deposits of Southeastern Alaska, GSA Geosphere, in press.

Balco, G., Stone, J. O., Lifton, N. A., and Dunai, T. J.: A complete and easily accessible means of calculating surface exposure ages or erosion rates from $10 \mathrm{Be}$ and $26 \mathrm{Al}$ measurements, Quaternary Geochronology, 3, 174-195, https://doi.org/10.1016/j.quageo.2007.12.001, 2008.

Balco, G.: Production rate calculations for cosmic-ray-muon-produced $10 \mathrm{Be}$ and $26 \mathrm{Al}$ benchmarked against geological calibration data, Quaternary Geochronology, 39, 150$173,2017$.

Barrie, J. V., and Conway, K. W.: Late Quaternary glaciation and postglacial stratigraphy of the northern Pacific margin of Canada, Quaternary Research, 51, 113-123, 1999.

Begét, James E., and Roman J. Motyka. "New dates on late Pleistocene dacitic tephra from the Mount Edgecumbe volcanic field, southeastern Alaska." Quaternary Research 49.1 (1998): 123-125.

Blaise, B., Clague, J. J., and Mathewes, R. W.: Time of maximum Late Wisconsin glaciation, West Coast of Canada, Quaternary Research, 34, 282-295, https://doi.org/10.1016/00335894(90)90041-I, 1990.

Booth, D. B., Troost, K. G., Clague, J. J., and Waitt, R. B.: The Cordilleran ice sheet, Developments in Quaternary Sciences, 1, 17-43, 2003.

Borchers, B., Marrero, S., Balco, G., Caffee, M., Goehring, B., Lifton, N., Nishiizumi, K., Phillips, F., Schaefer, J., and Stone, J. J. Q. G.: Geological calibration of spallation production rates in the CRONUS-Earth project, 31, 188-198, 2016.

Brew, David A.: Geologic map of the Craig, Dixon Entrance, and parts of the Ketchikan and Prince Rupert quadrangles, Southeastern Alaska, No. 95-215, 1995.

Briner, J. P., and Swanson, T. W.: Using inherited cosmogenic $36 \mathrm{Cl}$ to constrain glacial erosion rates of the Cordilleran ice sheet, Geology, 26, 3-6, 1998.

Briner, J. P., Tulenko, J. P., Kaufman, D. S., Young, N. E., Baichtal, J. F., and Lesnek, A.: The last deglaciation of Alaska, Cuadernos de investigación geográfica/Geographical Research Letters, 429-448, 2017.

Caissie, B. E., Brigham-Grette, J., Lawrence, K. T., Herbert, T. D., and Cook, M. S.: Last Glacial Maximum to Holocene sea surface conditions at Umnak Plateau, Bering Sea, as inferred from diatom, alkenone, and stable isotope records, Paleoceanography, 25, 2010.

Capps, S. R.: Glaciation in Alaska2330-7102, 1932.

Carrara, P. E., Ager, T. A., Baichtal, J. F., and VanSistine, D. P.: Map of glacial limits and possible refugia in the southern Alexander Archipelago, Alaska, during the late Wisconsin glaciation, Report 2424, 2003. 

southeastern Alaska during the late Wisconsin glaciation, Canadian Journal of Earth Sciences, 44, 229-244, 10.1139/e06-081, 2007.

Clague, J. J., Armstrong, J. E., and Mathews, W. H.: Advance of the late Wisconsin Cordilleran Ice Sheet in southern British Columbia since 22,000 Yr B.P, Quaternary Research, 13, 322-326, https://doi.org/10.1016/0033-5894(80)90060-5, 1980.

Cook, J. A., Bidlack, A. L., Conroy, C. J., Demboski, J. R., Fleming, M. A., Runck, A. M., Stone, K. D., and MacDonald, S. O.: A phylogeographic perspective on endemism in the Alexander Archipelago of southeast Alaska, Biological Conservation, 97, 215-227, https://doi.org/10.1016/S0006-3207(00)00114-2, 2001.

Corbett, L. B., Bierman, P. R., and Rood, D. H.: An approach for optimizing in situ cosmogenic 10Be sample preparation, Quaternary Geochronology, 33, 24-34, https://doi.org/10.1016/j.quageo.2016.02.001, 2016.

Cosma, T. N., Hendy, I. L., and Chang, A. S.: Chronological constraints on Cordilleran Ice Sheet glaciomarine sedimentation from core MD02-2496 off Vancouver Island (western Canada), Quaternary Science Reviews, 27, 941-955, https://doi.org/10.1016/j.quascirev.2008.01.013, 2008.

Dalton, A. S., Margold, M., Stokes, C. R., Tarasov, L., Dyke, A. S., Adams, R. S., Allard, S., Arends, H. E., Atkinson, N., and Attig, J. W.: An updated radiocarbon-based ice margin chronology for the last deglaciation of the North American Ice Sheet Complex, Quaternary Science Reviews, 234, 106223, 2020.

Darvill, C. M., Menounos, B., Goehring, B. M., Lian, O. B., and Caffee, M. W.: Retreat of the western Cordilleran ice sheet margin during the last deglaciation, Geophysical Research Letters, 45, 9710-9720, 2018.

Davies, M. H., Mix, A. C., Stoner, J. S., Addison, J. A., Jaeger, J., Finney, B., and Wiest, J.: The deglacial transition on the southeastern Alaska Margin: Meltwater input, sea level rise, marine productivity, and sedimentary anoxia, Palaeogeography and Palaeoclimatology, 26, 10.1029/2010pa002051, 2011.

Demboski, J. R., Stone, K. D., and Cook, J. A.: FURTHER PERSPECTIVES ON THE HAIDA GWAII GLACIAL REFUGIUM, Evolution, 53, 2008-2012, 10.1111/j.15585646.1999.tb04584.x, 1999.

Dyke, A. S.: An outline of North American deglaciation with emphasis on central and northern Canada, Developments in quaternary sciences, 2, 373-424, 2004.

Eberlein, G. D., Churkin, M., Carter, C., Berg, H., and Ovenshine, A.: Geology of the Craig quadrangle, Alaska, US Geological Survey, 2331-1258, 1983.

690 Fisher, D., Osterberg, E., Dyke, A., Dahl-Jensen, D., Demuth, M., Zdanowicz, C., Bourgeois, J., Koerner, R. M., Mayewski, P., and Wake, C.: The Mt Logan Holocene-late Wisconsinan isotope record: tropical Pacific-Yukon connections, The Holocene, 18, 667-677, 2008.

Gregoire, L. J., Otto-Bliesner, B., Valdes, P. J., and Ivanovic, R.: Abrupt Bølling warming and ice saddle collapse contributions to the Meltwater Pulse 1a rapid sea level rise, Geophysical research letters, 43, 9130-9137, 2016.

Hansen, B. C. S., and Engstrom, D. R.: Vegetation history of Pleasant Island, southeastern Alaska, since 13,000 yr BP, Quaternary Research, 46, 161-175, 1996. 
Ivanovic, R. F., Gregoire, L. J., Wickert, A. D., Valdes, P. J., and Burke, A.: Collapse of the North American ice saddle 14,500 years ago caused widespread cooling and reduced ocean overturning circulation, Geophysical Research Letters, 44, 383-392, 2017.

Jones, R. S., Whitehouse, P. L., Bentley, M. J., Small, D., and Dalton, A. S.: Impact of glacial isostatic adjustment on cosmogenic surface-exposure dating, Quaternary Science Reviews, 212, 206-212, 2019.

Kienast, S. S., and McKay, J. L.: Sea surface temperatures in the subarctic northeast Pacific reflect millennial-scale climate oscillations during the last 16 kyrs, Geophysical Research Letters, 28, 1563-1566, 2001.

Lal, D.: Cosmic ray labeling of erosion surfaces: in situ nuclide production rates and erosion models, Earth and Planetary Science Letters, 104, 424-439, 1991.

Lesnek, A. J., Briner, J. P., Lindqvist, C., Baichtal, J. F., and Heaton, T. H.: Deglaciation of the Pacific coastal corridor directly preceded the human colonization of the Americas, Science Advances, 4, eaar5040, 10.1126/sciadv.aar5040 \%J Science Advances, 2018.

Lesnek, A. J., Briner, J. P., Baichtal, J. F., and Lyles, A. S.: New constraints on the last deglaciation of the Cordilleran Ice Sheet in coastal Southeast Alaska, Quaternary

$715 \quad$ Research, 96, 140-160, 2020.

Maier, E., Zhang, X., Abelmann, A., Gersonde, R., Mulitza, S., Werner, M., Méheust, M., Ren, J., Chapligin, B., and Meyer, H.: North Pacific freshwater events linked to changes in glacial ocean circulation, Nature, 559, 241-245, 2018.

Mann, D. H.: Wisconsin and Holocene glaciation of southeast Alaska, 1986.

720 Mann, D. H., and Peteet, D. M.: Extent and Timing of the Last Glacial Maximum in Southwestern Alaska, Quaternary Research, 42, 136-148, https://doi.org/10.1006/qres.1994.1063, 1994.

Mann, D. H., and Hamilton, T. D.: Late Pleistocene and Holocene Paleoenvironments of the Pacific Coast, Quaternary Science Reviews, 14, 449-471, 10.1016/0277-3791(95)00016i, 1995.

Marrero, S. M., Phillips, F. M., Borchers, B., Lifton, N., Aumer, R.,and Balco, G: Cosmogenic nuclide systematics and the CRONUScalc program, Quaternary Geochronology, 31, 160187, 2016a.

Marrero, S.M., Phillips, F.M., Caffee, M.W. and Gosse, J.C.,: CRONUS-Earth cosmogenic ${ }^{36} \mathrm{Cl}$ calibration. Quaternary Geochronology, 31, 199-219, 2016b.

Mathewes, R. W., and Clague, J. J.: Paleoecology and ice limits of the early Fraser glaciation (Marine Isotope Stage 2) on Haida Gwaii, British Columbia, Canada, Quaternary Research, 88, 277-292, 10.1017/qua.2017.36, 2017.

Miller, R. D.: Gastineau channel formation: a composite glaciomarine deposit near Juneau, Alaska, US Government Printing Office, 1973.

Misarti, N., Finney, B. P., Jordan, J. W., Maschner, H. D. G., Addison, J. A., Shapley, M. D., Krumhardt, A., and Beget, J. E.: Early retreat of the Alaska Peninsula Glacier Complex and the implications for coastal migrations of First Americans, Quaternary Science Reviews, 48, 1-6, https://doi.org/10.1016/j.quascirev.2012.05.014, 2012.

740 Molnia, B. F.: Glaciers of North America-Glaciers of Alaska, Geological Survey (US), 2008.

Nishiizumi, K., Imamura, M., Caffee, M. W., Southon, J. R., Finkel, R. C., and McAninch, J.: Absolute calibration of 10Be AMS standards, Nuclear Instruments and Methods in Physics Research Section B: Beam Interactions with Materials and Atoms, 258, 403-413, https://doi.org/10.1016/j.nimb.2007.01.297, 2007. 
Porter, S. C., and Swanson, T. W.: Radiocarbon age constraints on rates of advance and retreat of the Puget lobe of the Cordilleran ice sheet during the last glaciation, Quaternary Research, 50, 205-213, 1998.

Praetorius, S., Mix, A., Jensen, B., Froese, D., Milne, G., Wolhowe, M., Addison, J., and Prahl, F.: Interaction between climate, volcanism, and isostatic rebound in Southeast Alaska during the last deglaciation, Earth and Planetary Science Letters, 452, 79-89, 2016.

Praetorius, S. K., and Mix, A. C.: Synchronization of North Pacific and Greenland climates preceded abrupt deglacial warming, Science, 345, 444-448, 2014.

Praetorius, S. K., Mix, A. C., Walczak, M. H., Wolhowe, M. D., Addison, J. A., and Prahl, F. G.: North Pacific deglacial hypoxic events linked to abrupt ocean warming, Nature, 527, 362-366, 2015.

Reger, R. D., Pinney, D. S., Burke, R. M., and Wiltse, M. A.: Catalog and initial analyses of geologic data related to middle to late Quaternary deposits, Cook Inlet region, Alaska, State of Alaska Division of Geological and Geophysical Surveys Report of Investigations, 95-96, 1996.

Riehle, J. R., Brew, D. A., Reed, K. M., and Bartsch-Winkler, S.: Explosive latest Pleistocene (?) and Holocene activity of the Mount Edgecumbe volcanic field, Alaska, US Geological Survey Circular, 939, 111-114, 1984.

Riehle, J. R., Champion, D. E., Brew, D. A., and Lanphere, M. A.: Pyroclastic deposits of the Mount Edgecumbe volcanic field, southeast Alaska: eruptions of a stratified magma chamber, Journal of volcanology and geothermal research, 53, 117-143, 1992.

Riehle, J. R.: The Mount Edgecumbe Volcanic Field: A Geologic History, US Department of Agriculture, Forest Service, Alaska Region, 1996.

Seguinot, J., Khroulev, C., Rogozhina, I., Stroeven, A. P., and Zhang, Q.: The effect of climate forcing on numerical simulations of the Cordilleran ice sheet at the Last Glacial Maximum, The Cryosphere, 8, 1087-1103, 2014.

Seguinot, J., Rogozhina, I., Stroeven, A. P., Margold, M., and Kleman, J.: Numerical simulations of the Cordilleran ice sheet through the last glacial cycle, The Cryosphere, 10, 639-664, 2016.

Shafer, A. B., Cullingham, C. I., Cote, S. D., and Coltman, D. W.: Of glaciers and refugia: a decade of study sheds new light on the phylogeography of northwestern North America, Mol Ecol, 19, 4589-4621, 10.1111/j.1365-294X.2010.04828.x, 2010.

Shafer, A. B. A., White, K. S., Côté, S. D., and Coltman, D. W.: Deciphering translocations from relicts in Baranof Island mountain goats: is an endemic genetic lineage at risk?, Conservation Genetics, 12, 1261-1268, 10.1007/s10592-011-0227-8, 2011.

780 Shakun, J. D., Clark, P. U., He, F., Marcott, S. A., Mix, A. C., Liu, Z., Otto-Bliesner, B., Schmittner, A., and Bard, E.: Global warming preceded by increasing carbon dioxide concentrations during the last deglaciation, Nature, 484, 49-54, 2012.

Spratt, R. M., and Lisiecki, L. E.: A Late Pleistocene sea level stack, Climate of the Past, 12, 1079-1092, 2016.

Staiger, J., Gosse, J., Toracinta, R., Oglesby, B., Fastook, J., and Johnson, J. V.: Atmospheric scaling of cosmogenic nuclide production: climate effect, Journal of Geophysical Research: Solid Earth, 112, 2007.

Stuiver, M., Reimer, P.J., and Reimer, R.W., CALIB 8.2, http://calib.org, 2021.

Tarasov, L., Dyke, A. S., Neal, R. M., and Peltier, W. R.: A data-calibrated distribution of deglacial chronologies for the North American ice complex from glaciological modeling, 
Earth and Planetary Science Letters, 315-316, 30-40, https://doi.org/10.1016/j.eps1.2011.09.010, 2012.

Taylor, M. A., Hendy, I. L., and Pak, D. K.: Deglacial ocean warming and marine margin retreat of the Cordilleran Ice Sheet in the North Pacific Ocean, Earth and Planetary Science Letters, 403, 89-98, 10.1016/j.epsl.2014.06.026, 2014.

Warner, B. G., Mathewes, R. W., and Clague, J. J.: Ice-free conditions on the Queen Charlotte Islands, British Columbia, at the height of late Wisconsin glaciation, Science, 218, 675677, 1982.

800

Wilcox, P. S., Dorale, J. A., Baichtal, J. F., Spotl, C., Fowell, S. J., Edwards, R. L., and Kovarik, J. L.: Millennial-scale glacial climate variability in Southeastern Alaska follows Dansgaard-Oeschger cyclicity, Sci Rep, 9, 7880, 10.1038/s41598-019-44231-1, 2019.

Wilson, F. H., Hults, C. P., Mull, C. G., and Karl, S. M.: Geologic map of Alaska, US Department of the Interior, US Geological Survey, 2015.

Young, N. E., Schaefer, J. M., Briner, J. P., and Goehring, B. M.: A ${ }^{10}$ Be production-rate 805 calibration for the Arctic, Journal of Quaternary Science, 28, 515-526, 2013. 


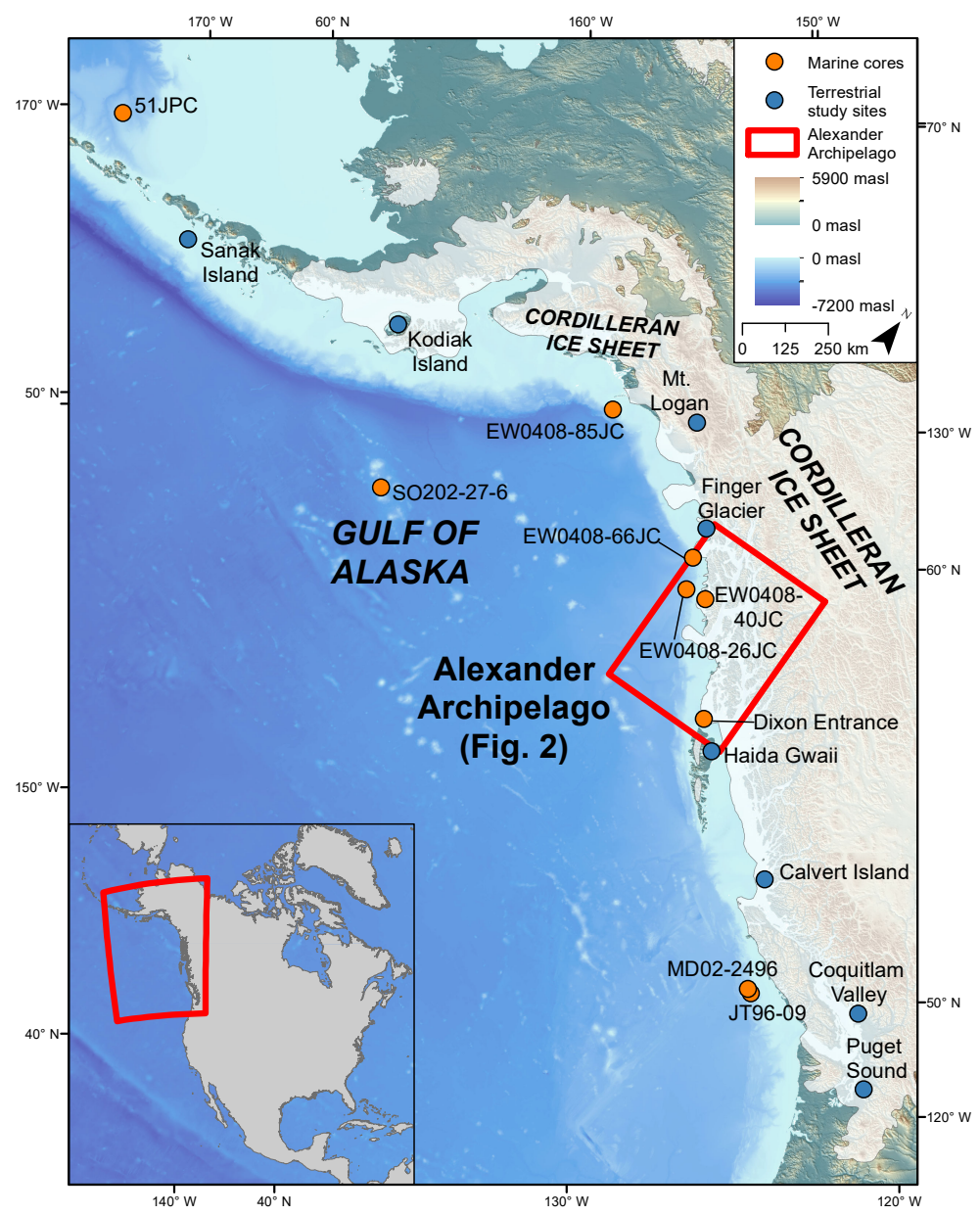

Figure 1: Map of the north Pacific region showing ice limits at 18.0 ka from Dalton et al. (2020) with location of relevant sites mentioned in the text. The Alexander Archipelago is highlighted by the red box. Orange dots indicate locations of marine sediment cores: 51-JPC (Caissie et al., 2010), SO202-27-6 (Maier et al., 2018), EW0408-85JC (Davies et al., 2011; Praetorius and Mix, 2014, Praetoruis et al., 2015), EW0408-66JC (Praetorius and Mix, 2014; Praetorius et al., 2016), EW0408-26JC (Praetorius and Mix, 2014; Praetorius et al., 2016), EW0408-40JC (Addison et al., 2010), MD02-2496 (Cosma and Hendy, 2008), and JT96-09 (Kienast and McKay, 2001). Blue dots indicate location of terrestrial study sites: Sanak Island (Misarti et al., 2012), Kodiak Island (Mann and Peteet, 1994), Mt. Logan (Fisher et al., 2008), Finger Glacier (Mann 1986), Haida Gwaii (Clague et al.,1982; Mathewes and Clague, 1982), Calvert Island, (Darvill et al., 2018), Coquitlam Valley (Clague et al., 1980), and Puget Sound (Porter and Swanson, 1998). 


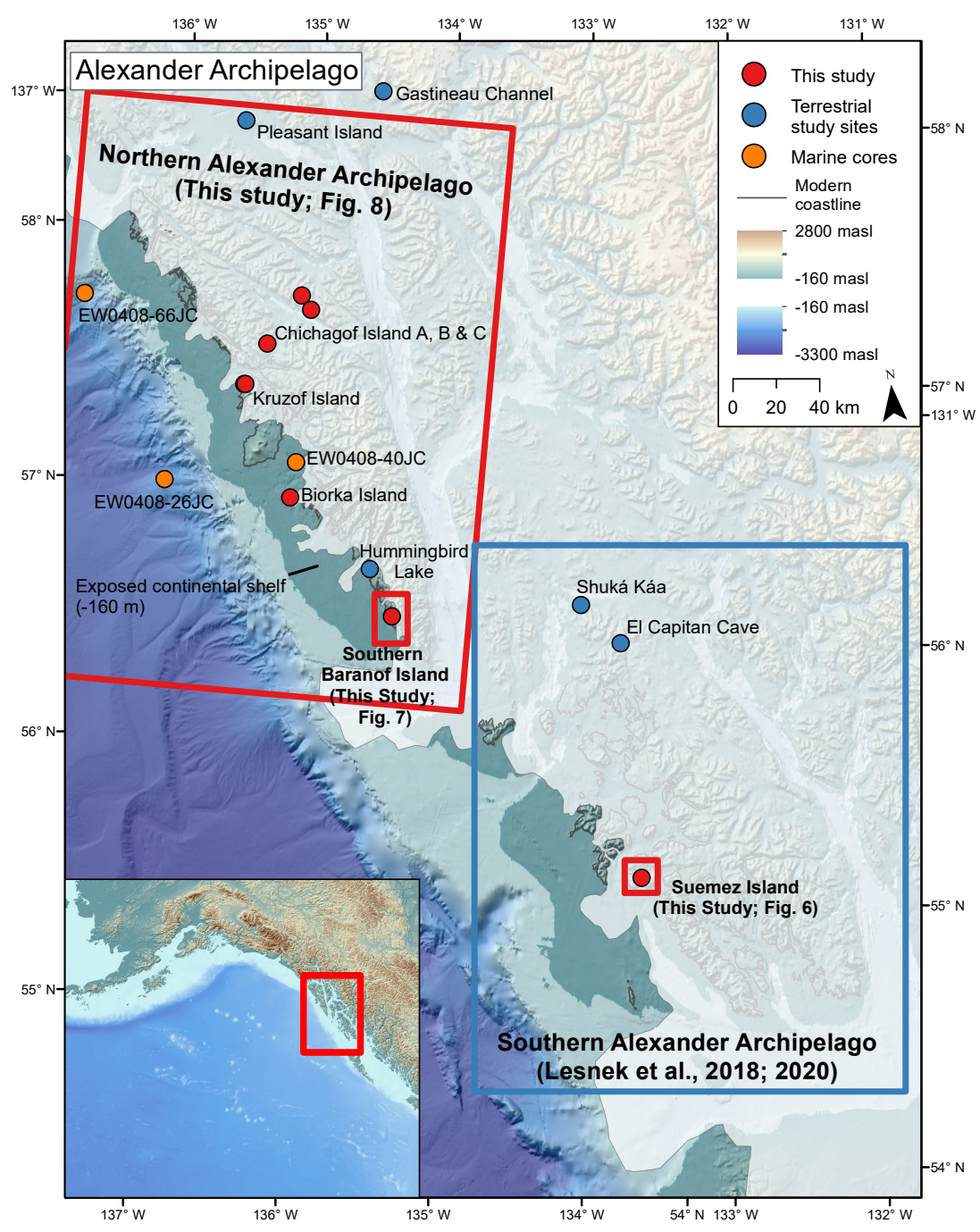

840 Figure 2: The Alexander Archipelago showing relevant marine sediment cores and terrestrial chronologies. Shaded white areas show hypothesized ILGM CIS extent (Lesnek et al., 2020). $160 \mathrm{~m}$ relative sea level lowering after Baichtal et al. (in press). Red boxes and points show sampling locations from this study. Blue box shows extent of study area from Lesnek et al. (2018; 2020). Orange dots represent locations of marine sediment cores: EW0408-66JC and 845 EW0408-26J (Praetorius and Mix, 2014; Praetorius et al., 2016) and EW0408-40JC (Addison et al., 2010). Blue dots indicate locations of relevant terrestrial study sites: Gastineau Channel (Miller, 1973), Pleasant Island (Hansen and Engstrom, 1996), Hummingbird Lake (Ager, 2019), Shuká Káa (Lesnek et al., 2018), and El Capitan Cave (Wilcox et al., 2019). 
https://doi.org/10.5194/gchron-2021-36

Preprint. Discussion started: 15 November 2021

(c) Author(s) 2021. CC BY 4.0 License.
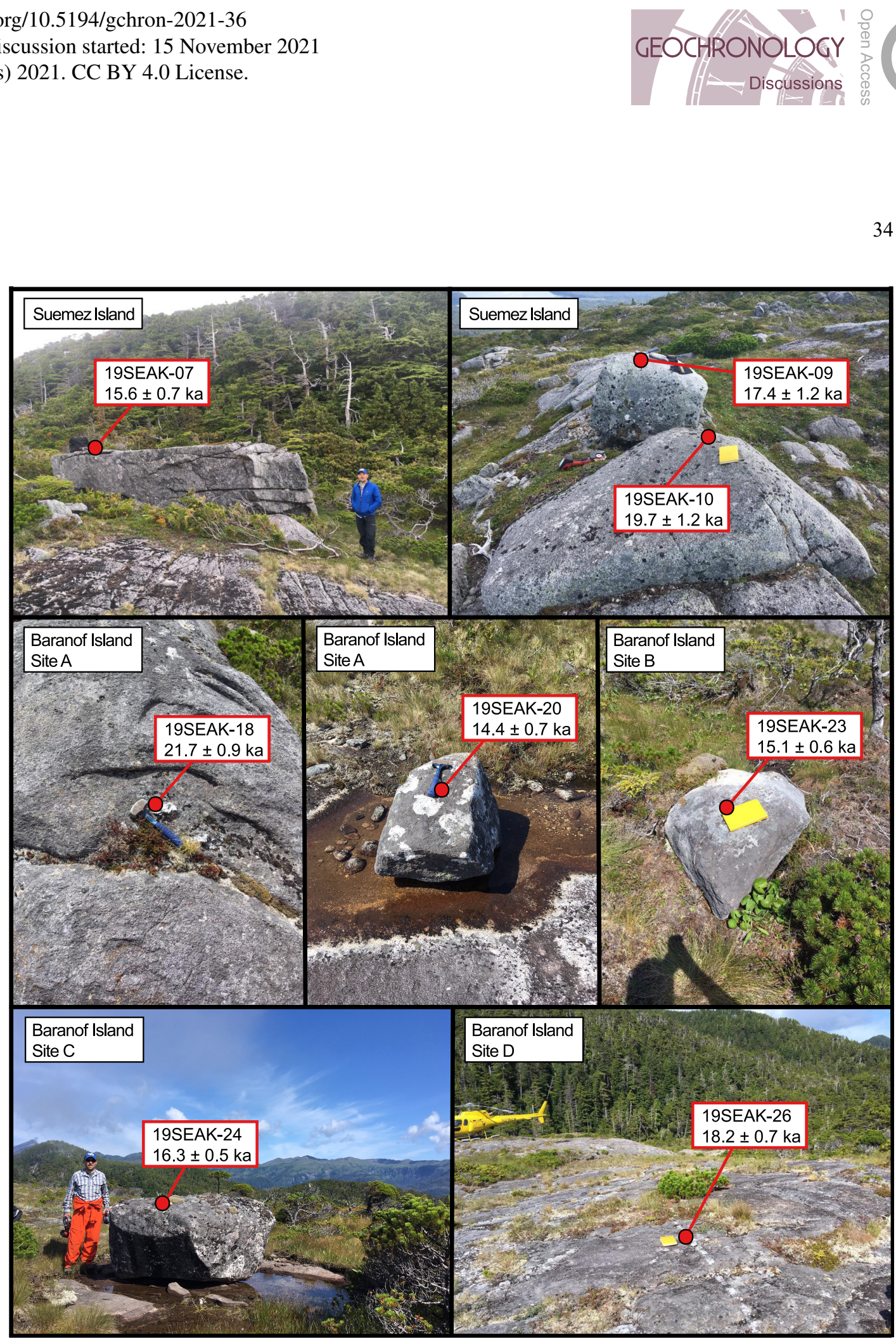

850 Figure 3: Sample photos from 2019 field season. All ${ }^{10}$ Be ages shown with $1 \sigma$ internal uncertainty. Note the grooves and chatter marks on bedrock of 19SEAK-18. 
https://doi.org/10.5194/gchron-2021-36

Preprint. Discussion started: 15 November 2021

(c) Author(s) 2021. CC BY 4.0 License.
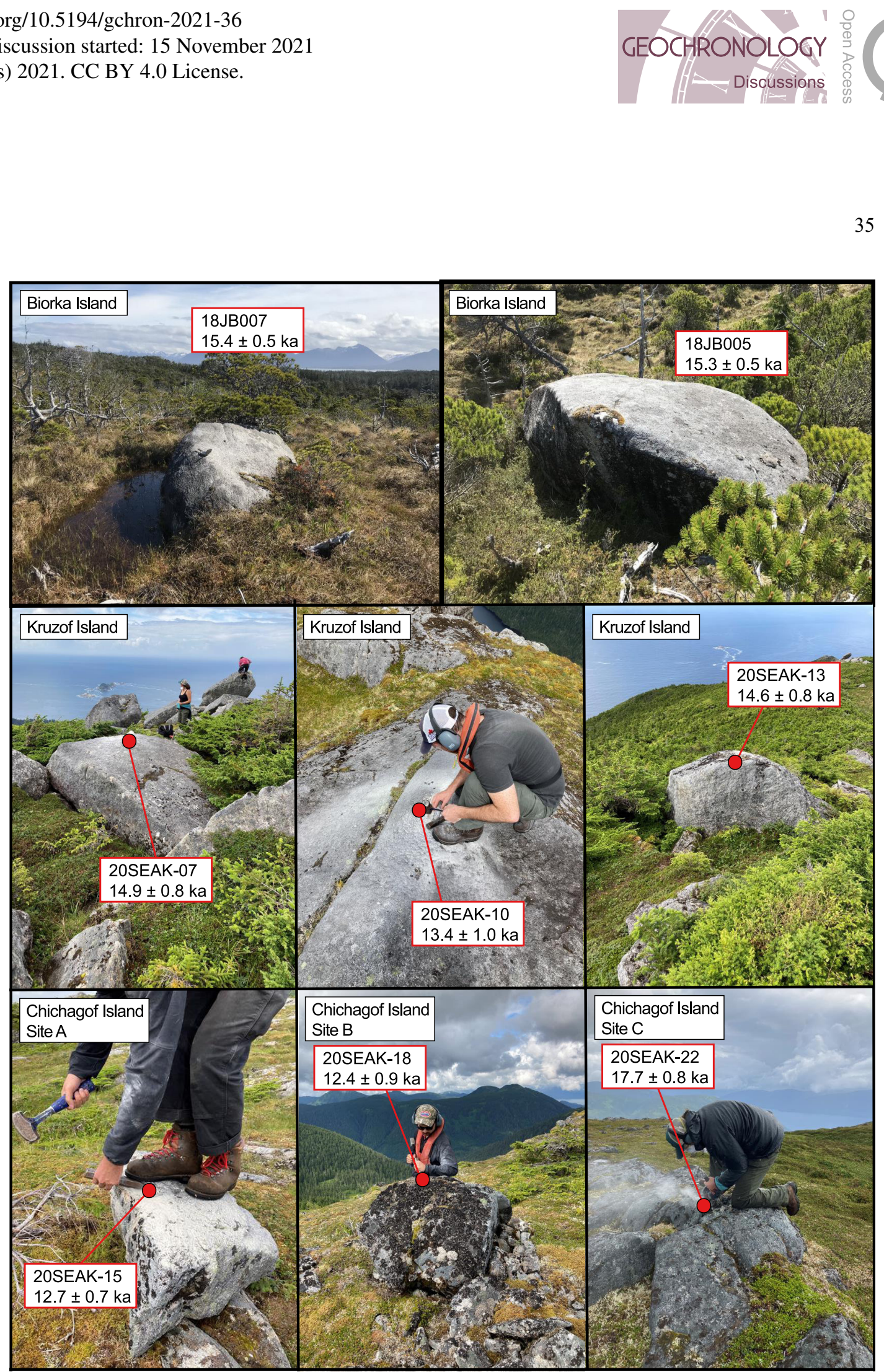

Figure 4: Sample photos from 2018 and 2020 field season. All ${ }^{10}$ Be ages are shown with $1 \sigma$ internal uncertainty. Note the relatively small size of 20SEAK-15. 
https://doi.org/10.5194/gchron-2021-36

Preprint. Discussion started: 15 November 2021

(c) Author(s) 2021. CC BY 4.0 License.
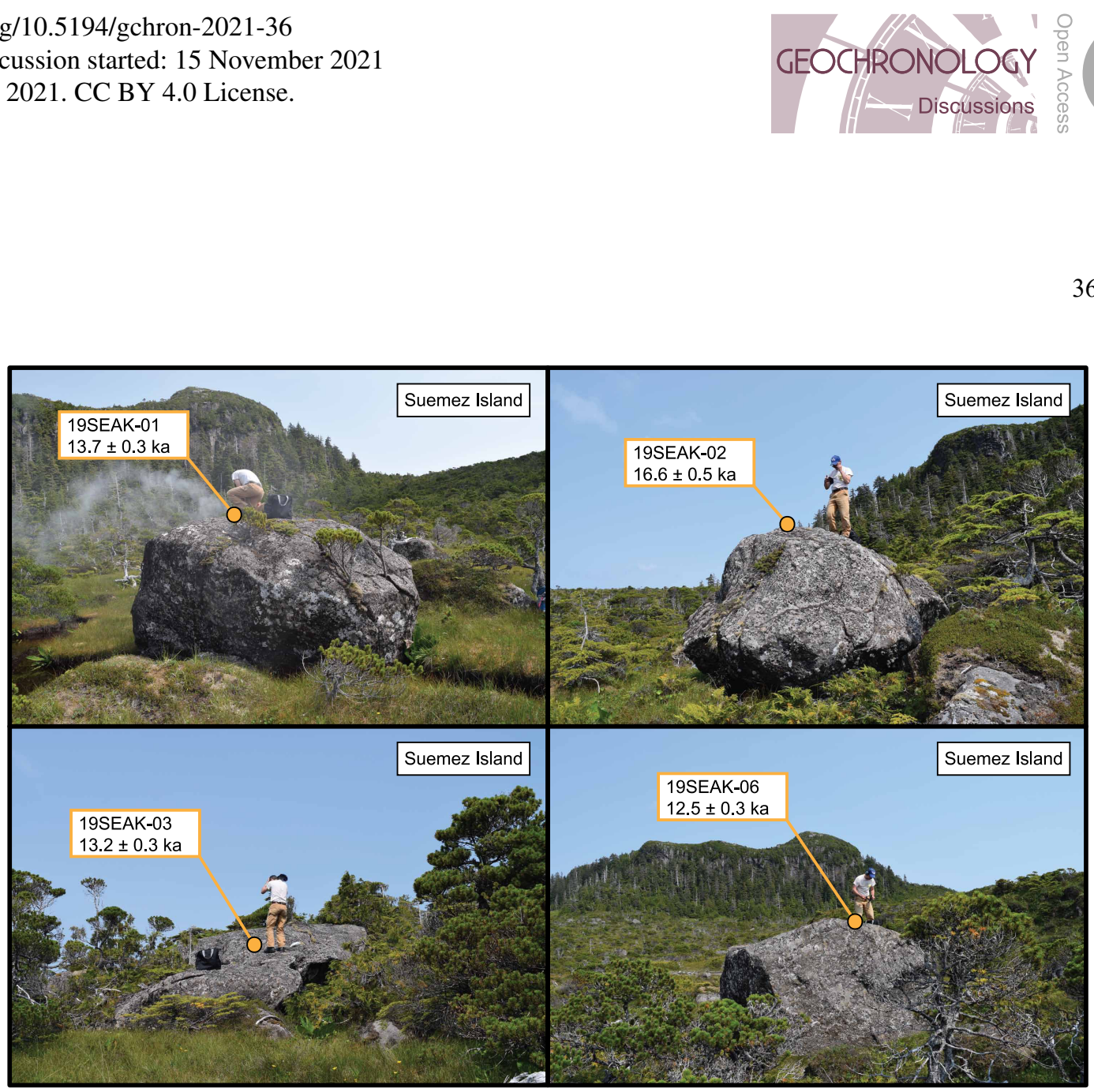

Figure 5: Basalt samples and ${ }^{36} \mathrm{Cl}$ ages from southwestern Suemez Island. Ages are reported at 1 $\sigma$ internal uncertainty. 
870 Table 1: ${ }^{10} \mathrm{Be}$ surface exposure age data.

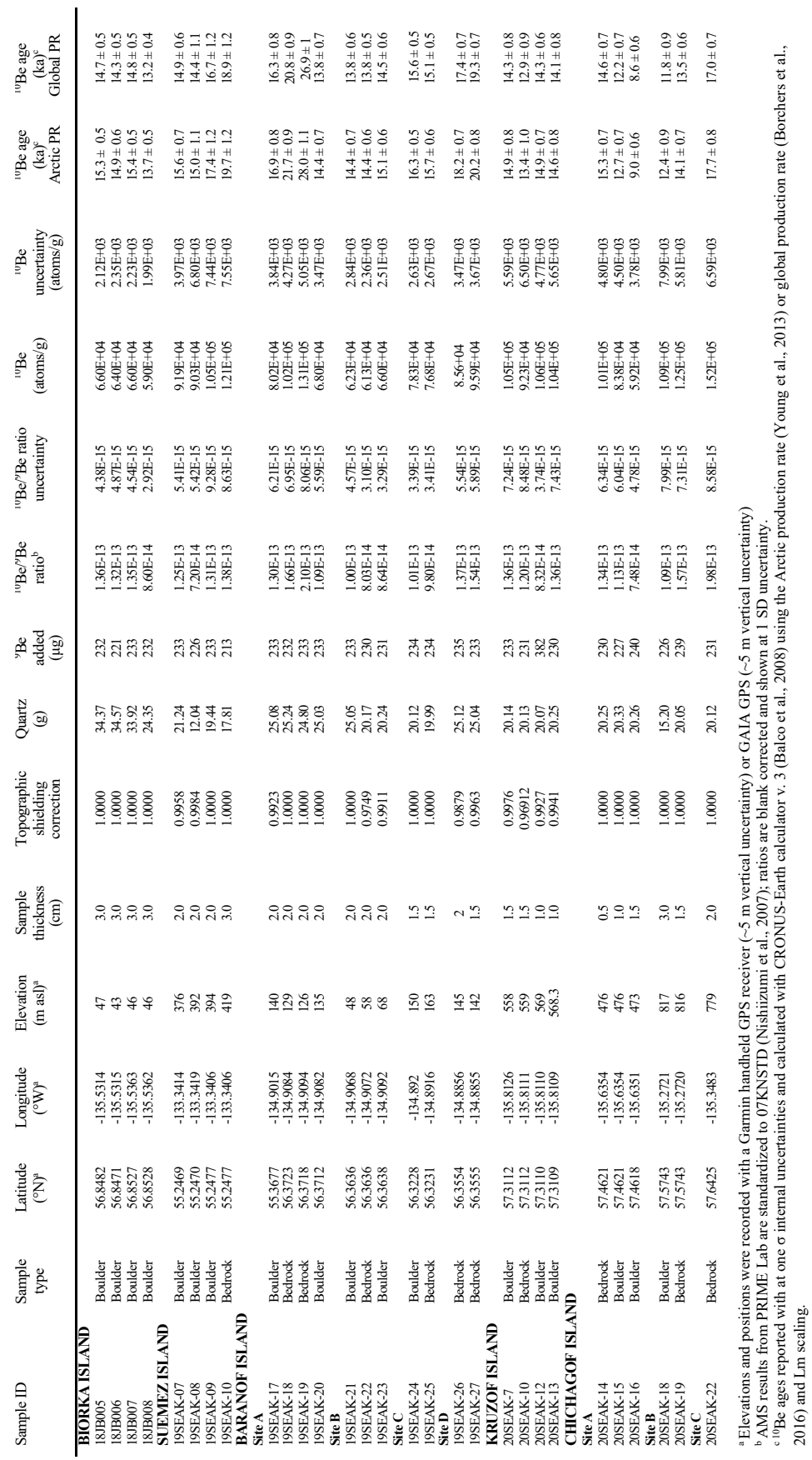


https://doi.org/10.5194/gchron-2021-36

Preprint. Discussion started: 15 November 2021

(c) Author(s) 2021. CC BY 4.0 License.

Table $2:{ }^{36} \mathrm{Cl}$ surface exposure age data

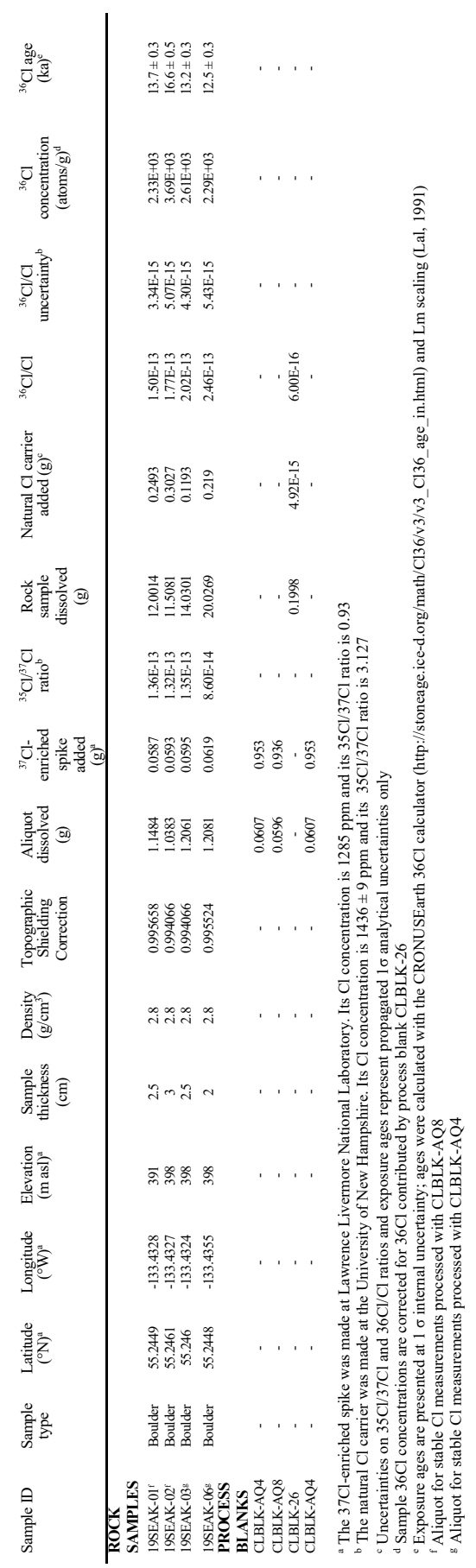




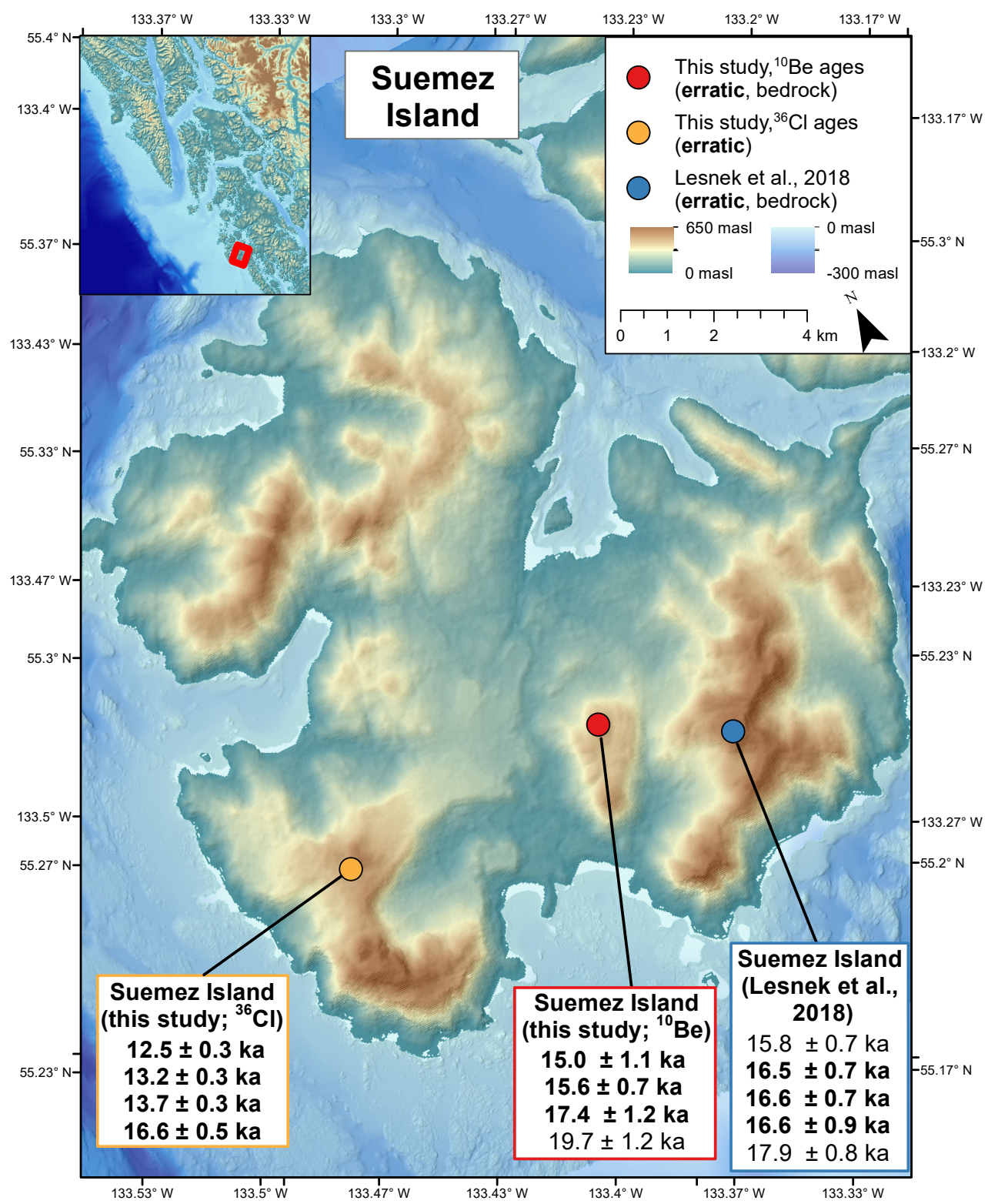

Figure 6: ${ }^{10} \mathrm{Be}$ and ${ }^{36} \mathrm{Cl}$ ages from samples collected on Suemez on island: red dot marks sampling site from this study, blue dot marks sampling site from Lesnek et al., 2018). All ${ }^{10} \mathrm{Be}$ and ${ }^{36} \mathrm{Cl}$ ages reported with $1 \sigma$ internal uncertainty. 


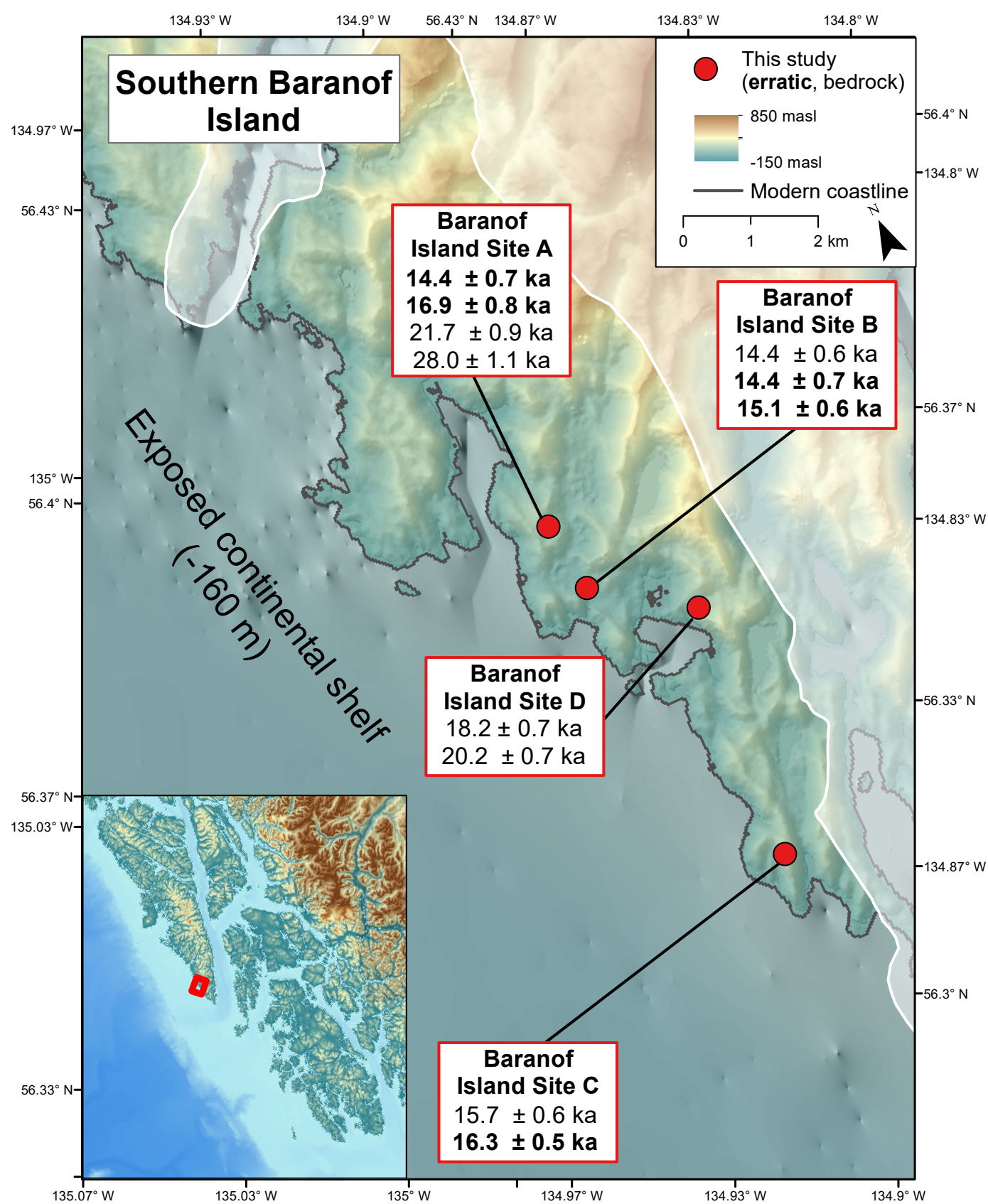

Figure 7: ${ }^{10} \mathrm{Be}$ ages from sampling sites on southern Baranof Island. All ages are reported with 1 $\sigma$ internal error. CIS ILGM extent after Carrara et al. (2007). 


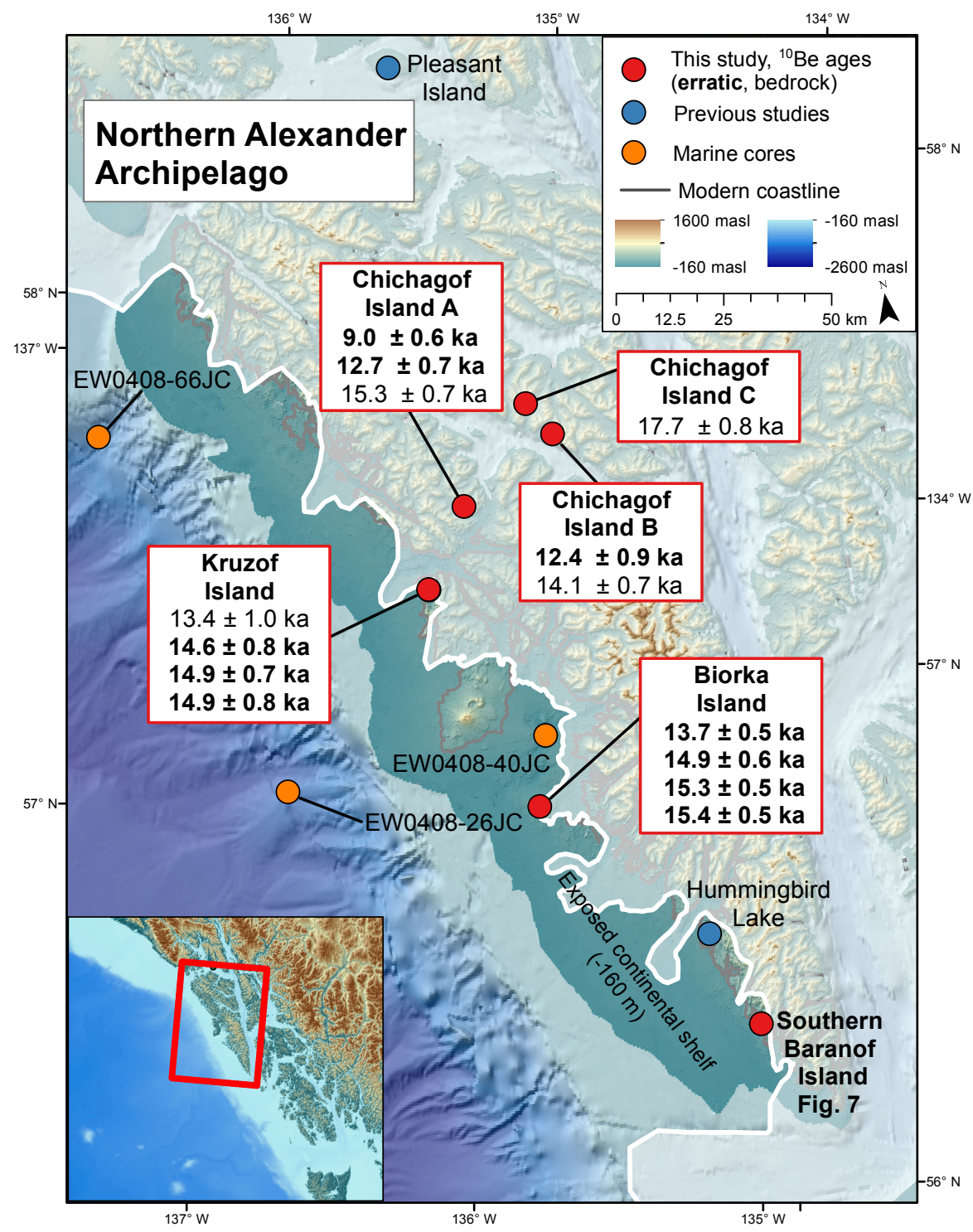

Figure 8: ${ }^{10} \mathrm{Be}$ ages from sampling sites in the northern Alexander Archipleago. All ages are reported with $1 \sigma$ internal error. ILGM CIS extent after Lesnek et al. (2020). Exposed continental shelf at $-160 \mathrm{~m}$ below modern sea level Baichtal et al. (in press). Yellow dots show location of relevant marine sediment cores: EW0408-66JC and EW0408-26JC (Praetorius and Mix, 2014; Praetorius et al., 2016) and EW0408-40JC (Addison et al., 2010). Blue dots show locations of relevant terrestrial study sites: Pleasant Island (Hansen and Engstrom, 1996) and Hummingbird Lake (Ager, 2019). 
https://doi.org/10.5194/gchron-2021-36

Preprint. Discussion started: 15 November 2021

(c) Author(s) 2021. CC BY 4.0 License.

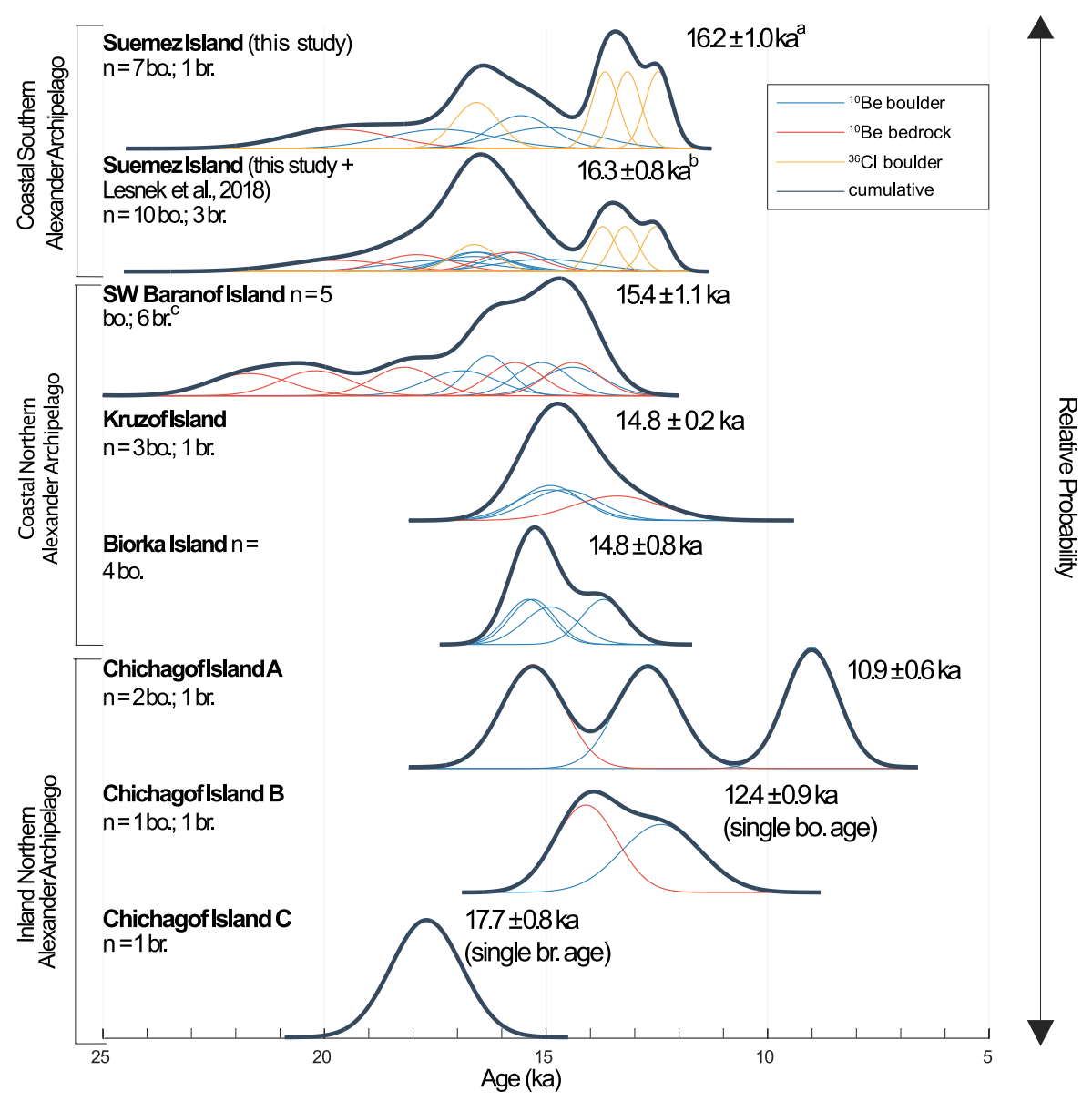

Figure 9: Relative probably plots of bedrock (red) and boulder (blue) ${ }^{10} \mathrm{Be}$ and ${ }^{36} \mathrm{Cl}$ boulder (yellow) ages from this study calculated with $1 \sigma$ internal uncertainty. bo. $=$ boulder, br. $=$ bedrock. All ages shown are mean ages from only boulders at each sample site reported with 1 SD unless noted. ${ }^{\text {a Average of all }}{ }^{10} \mathrm{Be}$ boulder ages and oldest ${ }^{36} \mathrm{Cl}$ boulder age with $1 \mathrm{SD}$. ${ }^{\mathrm{b}}$ Average of all ${ }^{10} \mathrm{Be}$ boulder ages (this study and Lesnek et al., 2018) and oldest ${ }^{36} \mathrm{Cl}$ boulder age (this study). ${ }^{\mathrm{c}}$ One old outlier at $28.0 \pm 1.1$ ka not shown. 


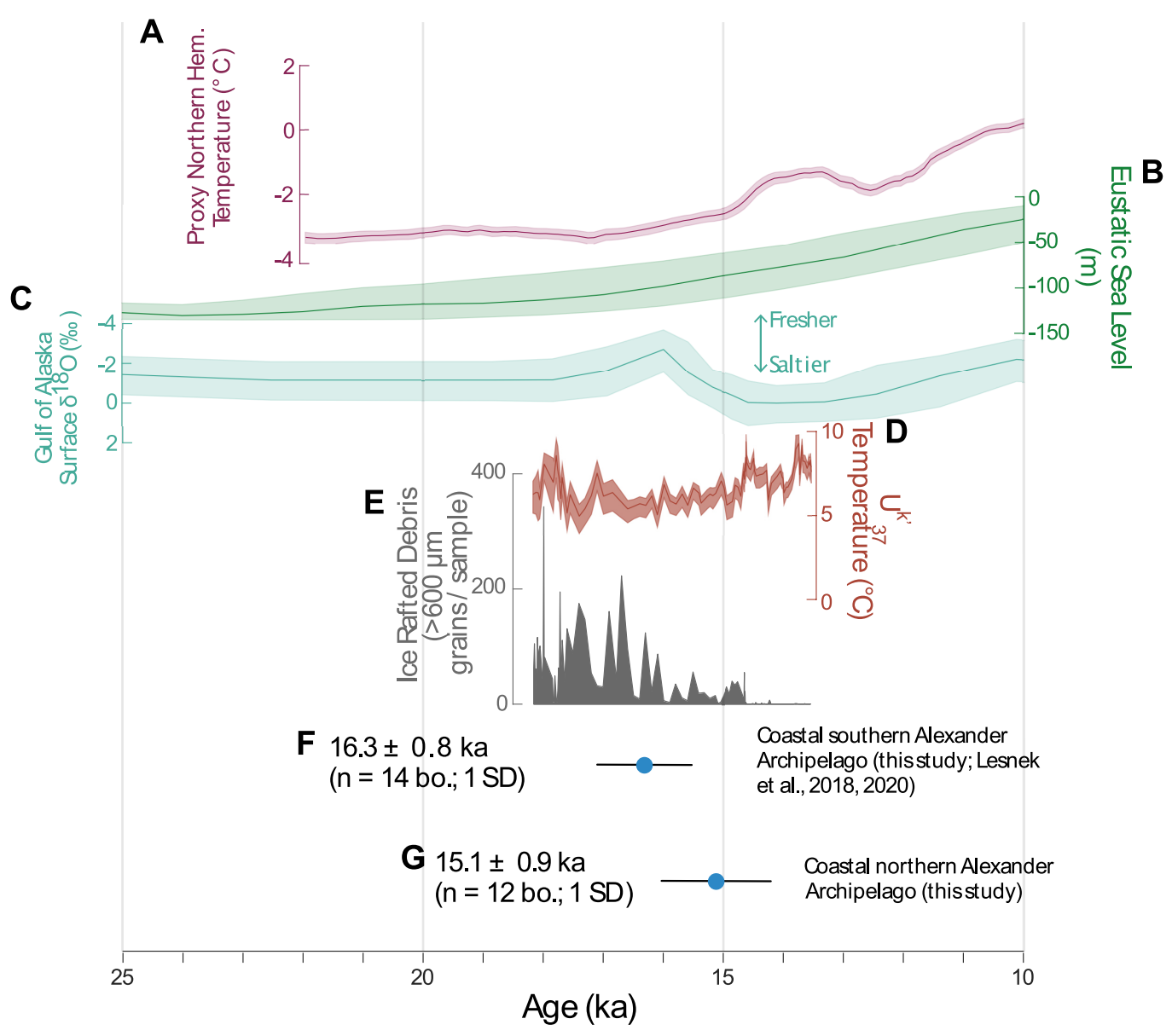

Figure 10: A) Proxy Northern Hemisphere temperature anomaly relative to early Holocene with $1 \sigma$ error (Shakun et al., 2012). B) Eustatic sea-level curve (Spratt and Lisiecki, 2016). C) Gulf of Alaska surface salinity $\delta^{18} \mathrm{O}$ record (Core SO202-27-6; Maier et al., 2018). D) $\mathrm{U}^{\mathrm{K}}{ }_{37}$ temperature reconstruction from off the coast of the Alexander Archipelago (Cores EW0408-26JC, EW040866JC; Praetorius et al., 2016). E) Ice rafted debris record from off Vancouver Island (Core MD02-2496; Cosma et al., 2008). F) - G) Relative probability plots of boulder ${ }^{10} \mathrm{Be}$ ages from the coastal Alexander Archipelago, with mean boulder ages and $1 \sigma$ reported (this study; Lesnek et al., 2018; 2020). 